\title{
Pseudo-Hegesippus at Antioch? Testing a Hypothesis for the Provenance of the De Excidio Hierosolymitano
}

Par

\section{Carson Bay}

Florida State University

7 his essay concerns the probable provenance of a particular text, colloquially referred to as 'Pseudo-Hegesippus' or On the Destruction of Jerusalem (De Excidio Hierosolymitano). Since this text is all but unknown within contemporary scholarship, I will begin with a brief overview and description. De Excidio is a Christian, Latin text from the late fourth century, probably circa $370 \mathrm{CE}$; it consists of five books, which largely follow, and condense, the seven books of Flavius Josephus' first-century work, the Judean War, which recounts the events leading up to, and the duration of, the Roman-Jewish War of 66-70/73 CE. ${ }^{1}$ A preface makes clear that De Excidio is written from a Christian viewpoint which values Josephus' historical veracity but deprecates his Jewish beliefs or ideology. Beginning

I would like to thank Andrea Di Giorgi and Alex Lee for their reviews of and comments on earlier renditions of this essay and I absolve them completely from any errors that may remain, which are my own. Funding for this research was provided generously by the Josephine de Karman Trust.

* The standard critical text for Pseudo-Hegesippus, and that cited here, is USSANI, Mras 1960; the older edition is WeBER, CAESAR 1864.

${ }^{1}$ Jerusalem was destroyed in $70 \mathrm{CE}$, and the final Jewish 'holdouts' of the war were killed atop the precipice of Masada in $73 \mathrm{CE}$. 
with this preface, the work imputes historical causality to God, with Jesus' life and death as the fulcrum, and purports to narrate the final destruction, the supremum excidium, of the Jews and their representative city of Jerusalem. The work may have been written in the wake of the Emperor Julian's abortive Temple rebuilding project. The text sources a great deal of material other than Josephus' Judean War, including 1 Maccabees, Josephus' Jewish Antiquities, the Hebrew Bible, the New Testament, and numerous classical sources such as Sallust, Horace, probably Livy, and others. While it follows the storyline of the Jewish War, it reinterprets events on multiple levels: sometimes minor changes or corrections from Josephus' narrative are visible; elsewhere, scenes are paraphrased, rewritten, omitted, or inserted (for example, an apocryphal legend of Peter and Paul appears at 3.2); sometimes De Excidio appears a paraphrase of the Judean War. Certainly, however, De Excidio is not a translation of the Judean War, and should not be confused or conflated with the Latin translation tradition of that work (with which it is likely coeval).

In Book 5, the author collapses Jewish War Books 5-7 into one book and departs substantially from Josephus, writing or rewriting major speeches of characters, inserting episodes and details and ekphrasis, and then ends the narrative abruptly at 5.53 with Eleazar's suicidal speech atop Masada. Overall, the work is a Christian rendition of the Jewish War that seeks to show how this war of the first century CE marked the effective end of the Jews as a theologically meaningful people on the stage of history. It is written in the style and language of classical historiography, and thus stands out within the church history or other Christian historiography of the fourth century. A more substantial survey to outline the book is beyond the scope of the present essay, but general scholarly familiarity with this text should be a goal within the field moving forward; there remains a great deal to be said about De Excidio, and its significance for scholarship on late antiquity has hardly begun to be realized.

De Excidio is a text little known and therefore rarely treated in scholarship. ${ }^{2}$ The only book-length treatments of the work to date, aside from the present author's recent dissertation, are the unpublished 1977 UNC Chapel Hill dissertation by Albert A. Bell, Jr.; ${ }^{3}$ the massivebut-unpublished 1987 dissertation of Dominique Estève, consisting of a French translation and commentary of Books $1-4 ;^{4}$ and a 2009 book in Italian by Chiara Somenzi entitled

\footnotetext{
${ }^{2}$ Albert Bell, who has done the most extensive work on this text to date, has suggested a reason for this: "If an ancient author wished to guarantee his own obscurity he could do so in one of several ways. He could begin by writing in the fourth century A.D., a period too late for most classicists and too early for most medievalists. Or he might be a Christian, so that scholars interested in secular writers would overlook him. Or, being a Christian, he might write about something other than theology or church history, so that patristic scholars would ignore him. As a last resort he might write anonymously, so that virtually everyone would pass him by. The late fourth-century Latin author known as pseudo-Hegesippus has the almost insuperable handicap of all four of these conditions weighing him down. As a result, he is all but unheard of except among a handful of late nineteenth and early twentieth-century scholars." (BELL 1980, p. 60). The first two factors that Bell lists are, in fact, increasingly non-issues due to the rising cadre of scholars studying late antiquity and their attendant scholarly production. The point that a Christian writer writing not-explicitly-Christian prose in late antiquity still does, in my opinion, increase the probability of that writer's work being marginalized within academic research.

${ }^{3}$ BELL 1977, which provides a very cursory examination of a number of speeches within the work, but which also contains important introductory information on the text and provides a useful overview of previous scholarship.

${ }^{4}$ ESTÈVE 1987. At 717 pages in three volumes, this work is substantial, and it makes the important point that De Excidio uses the conventions and idioms of classical historiography as its primary narrative medium; unfortunately, the work is difficult to access outside of France.
} 
Egesippo - Ambrogio: Formazione scolastica e Cristiana a Roma alla metà del IV secolo. ${ }^{5}$ The title of the latter work betrays its position relative to the question of authorship -De Excidio is colloquially attributed to an anonymous 'Pseudo-Hegesippus'- that has more or less predominated the sporadic scholarship on De Excidio over the past couple centuries. ${ }^{6}$

Somenzi's work is a novel and rather comprehensive reappraisal of the argument that Ambrose is the author of De Excidio, a position traditionally supported by reference to the early manuscript tradition, ${ }^{7}$ linguistic parallels, ${ }^{8}$ and incidental corroborating evidence. ${ }^{9}$ Somenzi reframes this argument by analyzing De Excidio by means of the scholastic culture the text evinces, its treatment of biblical tradition, its idiosyncratic position on suicide, its engagement with Christian apocryphal traditions, and its anti-Jewish polemic. She concludes provisionally that the methods and perspective manifest in De Excidio correspond so closely to the 'late fourth-century school of Ambrose,' that 'la soluzione economica' is to conclude "che Egesippo ... si sovrapponga fino ad identificarsi con il giovane Ambrogio." 10 For Somenzi, Pseudo-Hegesippus is 'the young Ambrose.' Yet despite Somenzi's creative and exemplary

\footnotetext{
${ }^{5}$ SOMENZI 2009. I refer readers to these two works on other formal questions concerning De Excidio, including the date, which in the present author's opinion falls fairly firmly within the late 360 s or early 370 s. I should also add that Somenzi's work in this area has been underway for some time; see, e.g., her earlier SOMENZI 2005, p. 741-780.

${ }^{6}$ One of the staunch supporters of Ambrosian authorship, and the most significant in terms of his effect on modern scholarship, is Vincenzo Ussani, editor of the text's critical edition (which remains quite adequate, despite several manuscripts that do not appear in its apparatus); see, e.g., UsSANI 1906, p. 245-361. But Ussani's work followed upon earlier studies that had concluded by various means that Ambrose either was or probably was De Excidio's author: e.g., WEYMAN 1905-06, p. 41-61; LANDGRAF 1902, p. 465-472; RÖNSCH 1883, p. 256321. It is noteworthy that already in $1889 \mathrm{Ihm}$ could call the controversia over De Excidio's authorship "vetus" (IHM 1889, p. 61). Ambrosian authorship, however, has always been contested when it has been suggested. Shortly after Ussani's work there appeared the subsequently published dissertation of SCHOLZ 1909, p. 149-195, who made the rather forceful statement "dass man zurzeit kein Recht habe, durch die Annahme der Ambrosianität die Autorfrage des Hegesippus als gelöst anzugeben” (p. 151).

${ }^{7}$ Codex Ambrosianus C 105 , the earliest mss $\left(5^{\text {th }}-6^{\text {th }}\right.$ century, at least in part) of De Excidio, yet which lacks the work's beginning, has at the end of Book 1: "EGESIPPI LIB PRIMUS EXPL INCP SECD AMBROSE EPI DE GREGO TRANSTULIT IN LATINUM.” See UsSANI, Mras 1960 [1932], p. 128 n. Ussani suggested for this reading: "Ambrosius episcopus de graeco transtulit in latinum," which does appear in several ninth- and tenth-century manuscripts (USSANI 1933, p. 115-116; BELL 1977, p. 23).

${ }^{8}$ See LANDGRAF 1902 (p. 86); LUMPE 1968, p. 165-167. However, note that also on the basis of vocabulary and style one finds the opposing argument (i.e. against Ambrosian authorship) in VoGEL 1880; SCHOLZ 1909; MorIN 1914-19, p. 83-91; MCCORMICK 1935, p. 212. Concerning style, Karl Mras went so far as to state that De Excidio "von dem des Ambrosius mehr abweicht als Gemeinsames mit ihm hat" (MRAS 1958, p. 147)!

${ }^{9}$ For example, early secondary attribution, the earliest example of which usually mentioned is William of Malmesbury's Gesta Regnum Anglorum. He inserts this note: "Hegesippus, a Greek author of the second century, wrote an account of the Jewish war, and of the destruction of Jerusalem; said to have been translated into Latin by St. Ambrose. He also wrote an ecclesiastical history, in five books, a fragment of which only remains." See GILES 1847, p. 378. Here William conflates the second-century Hegesippus mentioned by Eusebius, and the "Hegesippus" to whom is attributed De Excidio, a mix-up not uncommon in history and scholarship. It is poetic, perhaps, that William brings up (Pseudo-) Hegesippus in the context of describing Antioch on the Orontes! (See further discussion below.)

${ }^{10}$ SomenZI 2009, p. 189. This is in line with Otto Bardenhewer's earlier suggestion that De Excidio was a "jugendarbeit" of Ambrose; BARDENHEWER 1923, p. 505. Bardenhewer here also voices his doubt that Cassiodorus could have been referring to De Excidio in his mention of a Latin translation of the seven-book Jewish War (Cassiodorus Institutes 1.17.1), but states rather that he must have been speaking of the translation attributed to Rufinus, and then mistakenly connected Ambrose with the seven-book Latin translation of the Judean War.
} 
work, the authorship of De Excidio remains uncertain. ${ }^{11}$ Moreover, for present purposes, it is significant that Somenzi's concentration on la paternità Ambrogio prevents her study from truly broaching the question of provenance: her short introduction on "La 'Questione dell'Egesippo" (p. 3-10) only has sections on the related subjects of "La questione dell'autore" and "Le ipotesi di datazione."12 This omission is understandable given the scope and assumptions of Somenzi's project, and given that Antioch has only once, briefly, been suggested as a possible provenance for the work. Nevertheless, Milena Raimondi has recently suggested that Antioch and Antiochene cultural elements are still highly relevant to the discussion, whether or not one argues for Ambrosian authorship. ${ }^{13}$ The present study thus begins without Somenzi's assumptions, offering an alternative narrative regarding the provenance and (known or unknown) authorship of De Excidio.

The questions of authorship and of provenance are closely tied. The idea of Rome as the probable place of De Excidio's writing has accompanied arguments for Ambrosian authorship, and is the primary feature of Somenzi's treatment, present in her book's title (and in her methodology). But, like its authorship, the provenance of De Excidio is an unsettled issue. ${ }^{14}$ And another suggestion has been made concerning De Excidio's provenance, as mentioned above. Albert Bell, in the course of his dissertation's introductory chapter, mused that Syrian Antioch comprised a feasible candidate as the place of De Excidio's penning based upon several pieces of internal evidence. Bell's suggestion has received little attention, perhaps because his dissertation was never published, perhaps because so few scholars have written on De Excidio in the past half-century, and because among those that have few have fixated upon

${ }^{11}$ As an example of ongoing debate, Roberto Alciati has argued that "literary criticism alone is inadequate and tends to raise more questions than it answers," and also points out Somenzi's failure to engage the older and argument of Oberhleman, at odds with her own, that the prose rhythms of Ps-Heg and Ambrose are respectively distinct. See AlCIATI 2011, p. 359-361. On the cursus mixtus of Ambrosian literature see OBERHLEMAN 1991, p. 50ff. Given the sparsity of evidence overall, perhaps we should have some sympathy for scholars who allow for a probability of Ambrosian authorship, but allow for uncertainty (something not at odds with the present exploratory approach); see, e.g., DWYER 1931, p. 179.

${ }^{12}$ She does note, however, the proximity of Ambrose's source(s) and the Antiochene tradition in a footnote dealing with the text's potential correlation to Julian's Temple rebuilding project (SOMENZI 2009, p. 10, n. 49), citing LEVENSON 2004, p. 409-460.

${ }^{13}$ RAIMONDI 2011, p. 135-147; Raimondi concludes her study (p. 147), remarking upon the connection between Rome and Antioch in the late fourth century, thus: "L'asse Roma-Antiochia, già evidenziato dagli studi moderni su Egesippo, resta quindi un element degno della massima attenzione e suscettibile di approfondimento anche nella prospettiva dell'ipotesi ambrosiana."

${ }^{14}$ Other than the option of Ambrosian authorship and/or Roman provenance, and Antiochene provenance (the case tested here), several other possibilities have been suggested: Ludwig Traube suggested Spain as a place of writing, since Isidore, Alvarus, and the Liber Scintillarum - all hailing from Spain - knew De Excidio (and they do represent a substantial proportion of the authors that seem to have known De Excidio in the late antique/early Medieval period); TRAUBE 1884, p. 477-478. Morin also adopted Spain as the likely provenance of De Excidio, and suggested as its author Nummius Aemilianus Dexter, Jerome's friend, son of a Spanish bishop, praetorian prefect in 395, and proconsul of Asia; see MORIN 1914-19, p. 90-91; Bell dismisses this suggestion because of the author's apparent knowledge of Syria and Palestine (BELL 1977, p. 25). Alternatively, Mras suggested that a Jew named Isaac known from Jerome's writings (and known to have been at Rome) penned De Excidio (see USSANI, MRAS 1960 [1932], vol. 2, p. xxxiii); this suggestion Bell dismisses, and I think rightly so, because Jerome presents Isaac (Commentary on Titus 3.9) as having pretended faith (se ... in Christum credidisse simulabat) and stirred up trouble within the Church (corda simplicium pervertisset) by problematizing discrepancies between the genealogies in the Gospels of Matthew and Luke (BELL 1977, p. 26). 
questions of authorship. ${ }^{15}$ Or perhaps it is because scholars have a hard time believing that an extensive work written in Latin is likely to have come from late antique Antioch. Whatever the reason, Bell's suggestion that De Excidio was written at Antioch, or was written by an Antiochene, has not received satisfactory analysis to date. The present essay examines and extends Bell's suggestion, and concludes that his suggestion offers the most plausible provenance of the text. By comparing the evidence alluded to by Bell to suggest that the author of De Excidio was from Antioch with what is known of the city in late antiquity (albeit still quite imperfectly), supplemented with other pieces of circumstantial evidence, I conclude that the author of De Excidio was either from Antioch or had some special connection to that city. I submit that scholarship on De Excidio should take seriously the possibility that 'PseudoHegesippus' was an Antiochene.

I begin by introducing evidence mentioned yet not extrapolated by Albert Bell that seems to point to Antioch as the provenance of De Excidio. ${ }^{16}$ I undertake a critical analysis of each of Bell's suggestions to the extent that this is possible. I then add several suggestions of my own to construct a cumulative case. I attempt throughout to do justice to the various forms of evidence that must be taken into account. In the end, I do not conclude that De Excidio was certainly written at Antioch. However, I do conclude that Bell's suggestion that De Excidio's author hailed from Antioch appears more plausible than the oft-assumed alternative-e.g., assumed Ambrosian authorship and/or Roman provenance-barring more concrete evidence. Given what we know, I submit that De Excidio quite probably had an Antiochene author.

\section{Praise of Antioch}

The first clue that Bell mentions connecting the author of De Excidio to Antioch comes in the form of two sections of the text that deal with that locale. The first is geographical: at $D e$ Excidio 1.41.1, the author follows Josephus' Judean War (1.512); the former is some form of translation-adaptation-paraphrase of the latter in large part. Both authors at this shared point in their narratives relate how Herod and his nobles escorted Archelaus to Antioch. De Excidio goes on to describe the city with a non-Josephan panegyric: usque ad urbem Syriae splendidissimam Antiochiam nomine. In Josephus, Archealus is escorted to Antioch. ${ }^{17}$ In De Excidio, he is escorted to "the most illustrious city in Syria, by the name of Antioch."

\footnotetext{
${ }^{15}$ Moreover, as an anecdotal aside, I would add that several scholars to whom the present author has spoken have expressed interest and even a tentative willingness to accept an Ambrosian attribution of De Excidio, whereas every scholar to whom he has mentioned the idea of an Antiochene author has evinced incredulity.

${ }^{16}$ This suggestion is sometimes cited approvingly yet without further argument, as in DöNITZ 2011, p. 951968: "Due to geographical descriptions, it has been suggested that the author might have lived in Antioch, maybe as a member of Antioch's exegetical school to which John Chrysostom also belonged" (p. 957, citing BELL 1977).

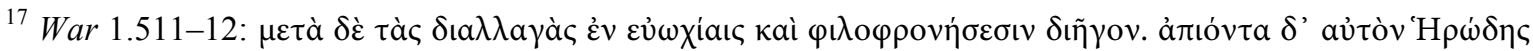

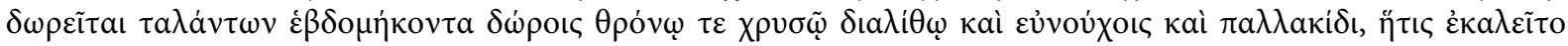

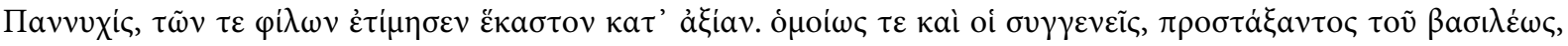

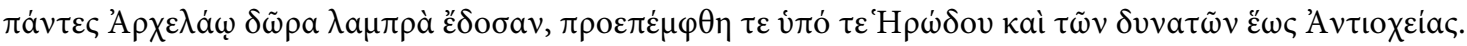

${ }^{18}$ Note the passage in comparison with Josephus' Greek (above): Hoc consilio soluta factio et conuersio facta in laetitiam, instauratum conuiuium initae indicium reconciliationis, cuius auctori Archelao LXX talenta et sedile aureum gemmis insignitum electi quoque eunuchi regali conferuntur magnificentia, et concubina, cui Pannychi nomen erat, dono datur atque accipitur. Similiter et propinqui monitu regis clarissimis donis Archelaum munerabantur, nec quisquam familiarium eius exors muneris fuit, quibus omnibus suis Herodes pro uniuscuiusque meritis plurima inpertiebat. Prosecutus est etiam cum potentibus suis usque ad urbem Syriae splendidissimam Antiochiam nomine in regnum suum regredientem (De Excidio 1.41.1).
} 
know from Libanius and authors (and orators) like him that it was commonplace for literary figures of late antiquity to praise their respective cities of origin, even to exaggeration, and that this was expected. ${ }^{19}$ An Antiochene himself, Libanius speaks in the superlative of Anti-

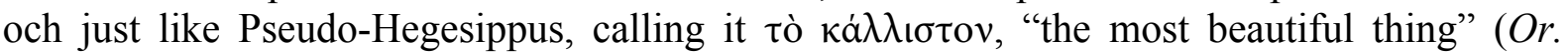
11.16a). ${ }^{20}$ The Christian orator John Chrysostom agreed, and spoke in terms of 'distinction' and 'precedence' of Antioch (On Statues 17.13-14), though for him a city's inhabitants were the acid test of its nobility. Libanius and Chrysostom are famous for their ties to Antioch, ${ }^{21}$ and De Excidio evinces a certain familiarity with the language of spectacle and oratory for which both Libanius and John Chrysostom were famous. ${ }^{22}$ Bell suggests that PseudoHegesippus, whoever he is, may also have had such ties, given what Bell sees as a "totally unnecessary outburst" that "has an almost patriotic fervor about it." ${ }^{, 2}$ Bell's suggestion is quite reasonable.

A pertinent parallel that might be adduced comes from Ammianus Marcellinus, an important near contemporary to Pseudo-Hegesippus. As in De Excidio, Ammianus inserts a short and unnecessary praise clause into his own narrative when he has Julian entering the city at 22.9.14: he calls Antioch orientis apicem pulcrum, "beautiful crown of the East." ${ }^{24}$ Elsewhere, while undertaking a geographical survey of Syria and its vicinity, Ammianus again references the civitas of Antioch and highlights its fame and extralocal preeminence: it is cognita mundo and "ennobles" (nobilitat) Syria. ${ }^{25}$ Pseudo-Hegesippus and Ammianus (and Libanius and Chrysostom) appear to be involved in a similar enterprise; though Antioch was a major urban hub of late antiquity, to praise it gratuitously is known to have been a habit of the city's more illustrious denizens.

${ }^{19}$ Downey calls "local patriotism and the praise of famous cities" "one of the fundamental factors of classical civilization;" DOWNEY 1959, p. 652. For further background concerning this practice regarding Antioch specifically, see NOCK 1954, p. 76-82.

${ }^{20}$ Further on Libanius' attachment to Antioch, see Oration 1.11-14 and WENZEL 2010, p. 269-270. More comprehensively, and for these chapters, see NORMAN 2000.

${ }^{21}$ On the former, see STENGER 2009, p. 42-43 et alibi. See 42n91 for bibliography on late antique Antioch, some of which is not mentioned in the current article (e.g., the articles by Ernest Will, Maurice, Sartre, Catherine Saliou, and Janine Balty in NiCOLET, IlBERT, DePAULE 2000).

${ }^{22}$ At De Excidio 5.2.1 Pseudo-Hegesippus employs the language of spectacle by: addressing the ciuitas of Jerusalem/the Jews in the second person (decepta est); enlisting the language of spectacle - that is, the employment of visual imagery in oratory or rhetoric - in both the indicative (quondam uidebaris beata) and the imperative (uide, aspice); making reference to oratorical terms (orationes, exordium, deploratio); and, arguably, by evoking the embodied action of the theatre in calling offstage witnesses to "arise" (exsurge) and "come forth" (suscitare). On the prominence of spectacle and theatre idiom in late-fourth century Christian thought, writing, and oratory, particularly that of John Chrysostom, see LEYERLE 2001.

${ }^{23}$ BELL 1977, p. 28

${ }^{24}$ 22.9.14: At hinc videre properans Antiochiam, orientis apicem pulcrum, usus itineribus solitis venit, urbique propinquans in speciem alicuius numinis votis excipitur publicis, miratus voces multitudinis magnae, salutare sidus inluxisse eois partibus adclamantis.

${ }^{25}$ 14.8.8: Dein Syria per speciosam interpatet diffusa planitiem. Hanc nobilitat Antiochia, mundo cognita civitas, cui non certaverit alia advecticiis ita adfluere copiis et internis, et Laodicia et Apamia itidemque Seleucia iam inde a primis auspiciis florentissimae. Comp. Ausonius Ordo Urbium Nobilium 5. Bell comparies Ausonius' praise of his home city Bourdeaux (Ordo 20) with the enthusiasm of Ammianus and PseudoHegesippus for Antioch (BELL 1977, p. 28). 


\section{Topographic Ekphrasis of Antioch}

In addition to his praise of the city, Pseudo-Hegesippus undertakes a lengthy topographical aside at 3.5.2. This ekphrasis has no parallel in the Judean War (see 3.8). Bell mentions this basically-accurate topographical-meteorological description of Antioch, noting rightly that "[f]or no other city which he mentions does he provide this sort of detailed information." 26 The description, which I quote here in full, is striking:

This city is held, without hesitation, to be the first, and for that reason the metropolis, of Syria, having been founded by the partisans of the warrior Alexander the Great and called by the name of its founder. The city is situated thus: spread out over an immense length, it is narrower in width, because it is bounded on the left side by the steep face of a mountain, such that the spaces of the city as measured were not able to be extended further. Necessity marked the location, because such a high mountain would provide a place to hide from the Parthians breaking in through unknown and alternate routes, from which they could pour themselves out by way of an unanticipated onset and immediate attack against an unprepared Syria, unless the city should lie before a mountain as before a bulwark and obstruct the egress of those approaching, so that if any of the barbarians should ascend, immediately he would be seen from the hollow center of the city. Eventually, they hold that, when theatrical plays were being frequented in that city, one of the farcical actors, raising his eyes to the mountain, saw the Persians arriving and immediately said: "I am either beholding a dream or a great danger. Behold: Persians!" This was possible because the mountain leaned over the city, so that not even the height of the theatre provided an impediment to seeing the mountain. A river separates it in the middle which, originating from the direction of the sun's rising, is joined to the sea not far from the city. This river those of former times called 'Orient' due to the tracing of its origin, inasmuch as they [those of former times] are commonly believed to have given names to places, names which were thereafter adopted. It is from the frigid flows of this river from its very onset, and from the Zephyrs blowing constantly through it in places, that the entire city is cooled at nearly every moment, so that it has hidden the East in its eastern parts. Within it are sweet waters, and without a nearby meadow surrounded by open spaces and clusters of cypress trees, as well as productive fountains. They call it Daphne, because it never sets aside its greenery. There there exists a populus numerous and very happy that is more refined than nearly all others of the East, but nearer to licentiousness. This city, having been reckoned to hold third place of all other citizen bodies which exist in the Roman world, now holds fourth place, after the citizen body of the Byzantines has produced Constantinople, once capital of the Persians, but now a means of defense. I believe enough has been said concerning the situation of the city. For it is not seemly to delay by describing its edifices. When I spoke of the East from its back, it was clear enough that the South is situated from the left, that Europe meets it from the front, that the Northern peoples live to the right, where also the Caspian kingdoms are held, who had previously been the most inclined to make incursions into Syria. But after Alexander the Great established the Caspian Gate at a steep part of the Taurus Mountain, and closed off the way to all the peoples of the interior, he returned the famous city to peace, except perhaps when observing Persian movement. ${ }^{27}$

\footnotetext{
${ }^{26}$ BELL 1977, p. 28.

${ }^{27}$ De Excidio 3.5.2: Vrbs ea Syriae sine retractatione prima ideoque metropolis habetur, condita ab his qui Alexandro Magno bellanti adhaesere, conditoris sui nuncupata uocabulo. Situs urbis: porrecta in inmensum longitudine, in lato angustior, quia praerupto montis a laeua artatur, ut extendi ulterius metandae urbis spatia nequirent. Necessitas locum signauit, quia per occulta et deuia inrumpentibus Parthis mons celsior latibulum
} 
Here an extensive topography and insertion of a traditional episode illustrate Antioch's geography, couched in the local lore of Alexander the Great/the diadochoi, which the author clearly knows. ${ }^{28}$ Numerous features of De Excidio's description ring true and, again, that such details are superfluous, and appear for no other city in Ps-Heg's narrative, is significant.

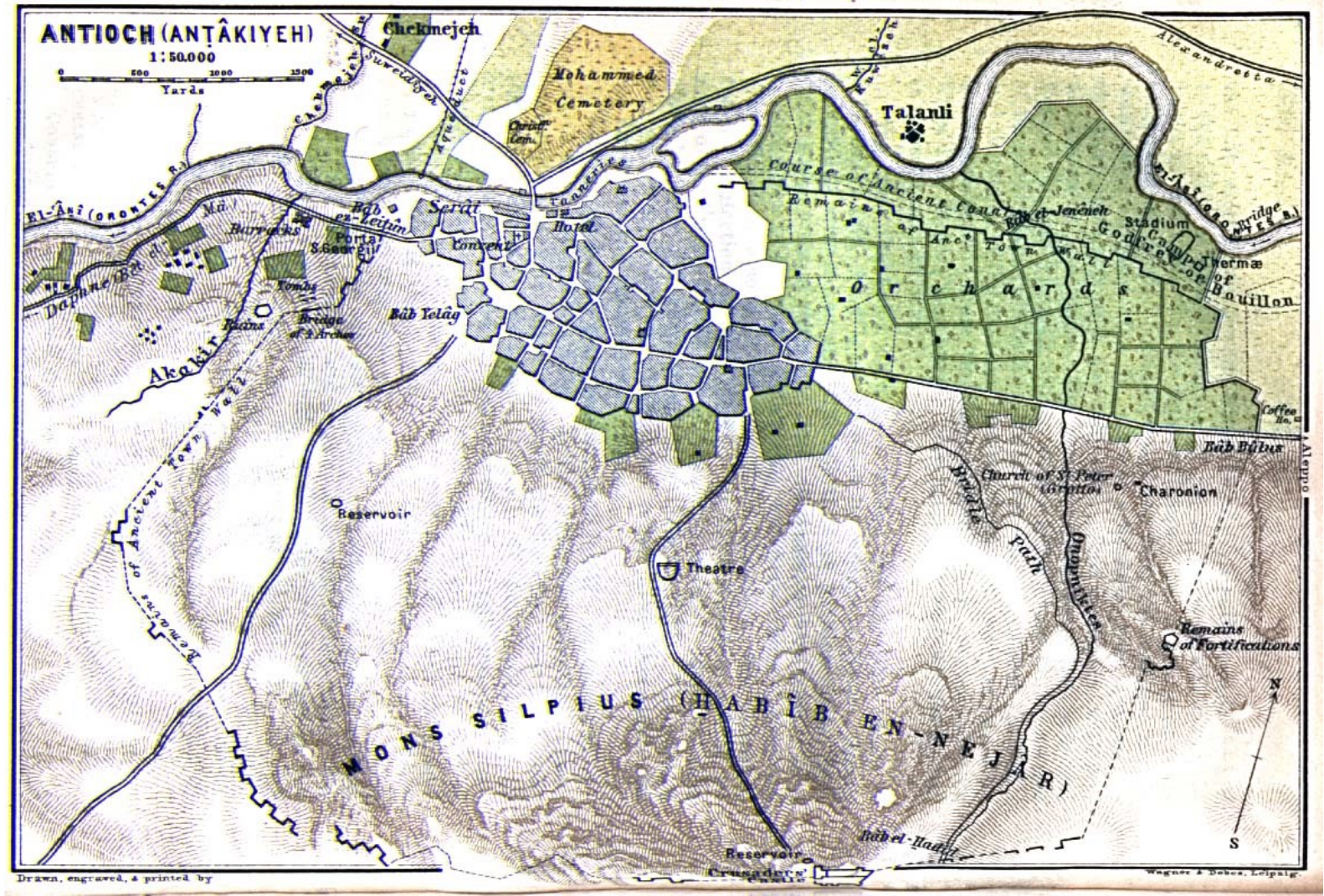

Fig. 1. Public Domain. From Karl Baedeker, Palestine and Syria, with the Chief Routes through Mesopotamia and Babylonia (Leipzig: Karl Baedeker, 1906), p. 382-83.

daret, ex quo se inopinato aduentu et promtiore impetu in imparatam Syriam effunderent, nisi ciuitas monti uelut claustrum obiaceret exitusque obstrueret aduenientibus, ut si quis barbarorum ascenderet, statim e medio urbis sinu prospectaretur. Denique ferunt, cum ludi scenici in ea urbe celebrarentur, quendam actorem mimorum eleuatis oculis ad montem Persas uidisse aduenientes et dixisse continuo: 'Aut somnium uideo aut magnum periculum. Ecce Persae'. Ita mons urbi praeminet, ut nec theatri altitudo ad prospiciendum montem impedimento sit. Fluuius eam medius intersecat, qui a solis ortu oriens non longe ab urbe in mare conditur, quem de originis suae tractu Orientem ueteres appellauerunt, ut uulgo putetur locis nomen dedisse, cum inde acceperit. Cuius fluentis ipso impetu frigidioribus et zephyris assiduo per ea locorum spirantibus tota ciuitas momentis prope omnibus refrigeratur, ut Orientis in partibus Orientem absconderit. Intus dulces aquae, foris finitimum nemus intextum cupressis crebris fontes atque uberes. Daphnen uocant, quod numquam deponat uiriditatem. Frequens et laetior populus ut pleraque Orientis facetiorque prope omnibus sed propior lasciuiae. Vrbs tertio loco ante ex omnibus, quae in orbe Romano sunt ciuitatibus aestimata, nunc quarto, postquam Constaninopolim excreuit ciuitas Byzantiorum, Persarum quondam caput, nunc repulsorium. De situ urbis satis dictum puto. Neque enim describendis eius aedificiis immorandum uidetur. Cuius a tergo cum orientem dixerim, satis liquet a laeua meridiem iacere, a fronte Europam occurrere, in dexteram septentrionales gentes degere Caspiaque regna haberi, quae ante promtissima ad incursandam Syriam erant. Sed postquam Alexander Magnus Caspiam portam Tauri montis praerupto inposuit atque omne interioribus gentibus interclusit iter, memoratam urbem quietam reddidit, nisi forte motus Persicos suspectantem.

${ }^{28}$ Compare this tradition to other late antique literature that references Alexander the Great and Antiochus as figureheads of Antioch's foundation, such as the Acta of Antioch, Stephanus of Byzantium, the Conciliar list of Constantinople II (553), Procopius, and Sophronius. See FRASER 1996, p. 9, n. 16. 
De Excidio's ekphrastic topography of Antioch first expatiates upon the city's length, which the author calls "immense" (inmensum) in length, yet shorter (angustior) in width due to the mountains that hem it in on what he calls its "left side." Even a more recent map of Antioch bears out this description (Fig. 1); indeed, the steep mountains hedging the city in are, to this day, unmistakable to any visitor.

The author of De Excidio need not have been a resident of Antioch to have known this, but it is provocative that Pseudo-Hegesippus mentions the mountains and Daphne's setting, complete with "sweet waters... a nearby meadow...open spaces and clusters of cypress trees."29 One reason this description is interesting, I submit, is due to a map.

In 1624 a certain Ortelius produced about 300 copies of a sizeable map created much earlier and known to him via a $12^{\text {th }}$ - or $13^{\text {th }}$-century copy, itself putatively copied from a fourth-century papyrus scroll. This map, called the "Peutinger Map" (Tabula Peutingeriana) after Konrad Peutinger (Fig. 2) ${ }^{30}$ recreates an original that would have measured some $71 / 2$ inches in height and $131 / 2$ feet in length. ${ }^{31}$ This map contains "large, figurative representations of Rome, Constantinople, and Antioch," 32 the latter having been rendered with particular care. ${ }^{33}$ Antioch appears with personified Tyche (perhaps) sitting a throne, ${ }^{34}$ surrounded by structures, rivers, and conspicuous trees. Pseudo-Hegesippus, like this map, thought to include mountains, rivers, and trees as the defining topographical features related to Antioch. Since this map - if indeed Antioch existed on the original map - was dated by Konrad Miller (who gifted the map to Peutinger) to $365-366,{ }^{35}$ a date very close to the most reasonable dating of De Excidio (soon after 367), ${ }^{36}$ we are justified in marking, at least tentatively, the correspondence between De Excidio's choice of details and those found on the map. The point here is that De Excidio's account is apparently accurate per its contemporary cartography; and while many might have known such generic aspects of Antioch, we must ask who would care to accentuate them within an otherwise unrelated narrative. ${ }^{37}$

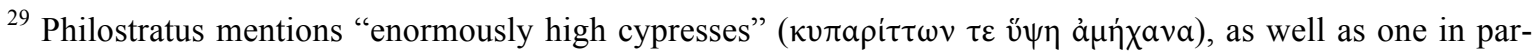
ticular with mythic associations, and laurel trees; in addition, he states that "the place produces plentiful, gentle

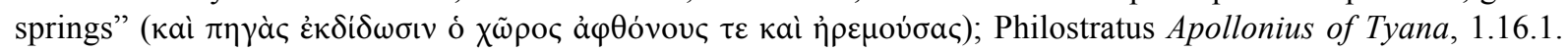
See JONES 2005, p. 68-69.

${ }^{30}$ Given to him by the German humanist Conrad Celtis around 1500. See the brief introduction in THROWER 2008, p. 39-40.

${ }^{31}$ See now, with an up-to-date bibliography, P. von Zabern, ed., Tabula Peutingeriana: Die einzige Weltkarte aus der Antike, Darmstadt, WBG, 2016.

32 TALBERT 2010, p. 77.

33 TALBERT 2010, p. 180. Albu finds it odd that Antioch should be larger than Rome and Constantinople on the map; see AlBU 2014, p. 100.

34 This could also be "the Virgin" or another ancient personification of the city itself; ALBU 2014, p. 100.

${ }^{35}$ See AlBu 2014, p. 95. According to John Vanderspoel, on the map "Antioch protects an individual who has sought protection, presumably from the Persians." VANDERSPOEL 1995, p. 59. See further concerning the map MiLler 1964; WeBER 1976; LEVI, LEVI 1967. Vanderspoel also mentions DILKE 1998 [1985], p. 113-120; see also the detailed discussion in DILKE 1987, p. 234-257.

${ }^{36}$ BELL 1977, p. 2.

${ }^{37}$ In passing, I would also mention De Excidio's meteorological note of the city's pleasant winds, and the texts concentration upon the quality of its waters; interestingly enough, these are things that stood out enough to later nineteenth century travelers that they recorded them in their notes; see, e.g., CARNE 1842, vol. 1, p. 18; ROBINSON 1837, vol. 2, p. 74, 347.
} 


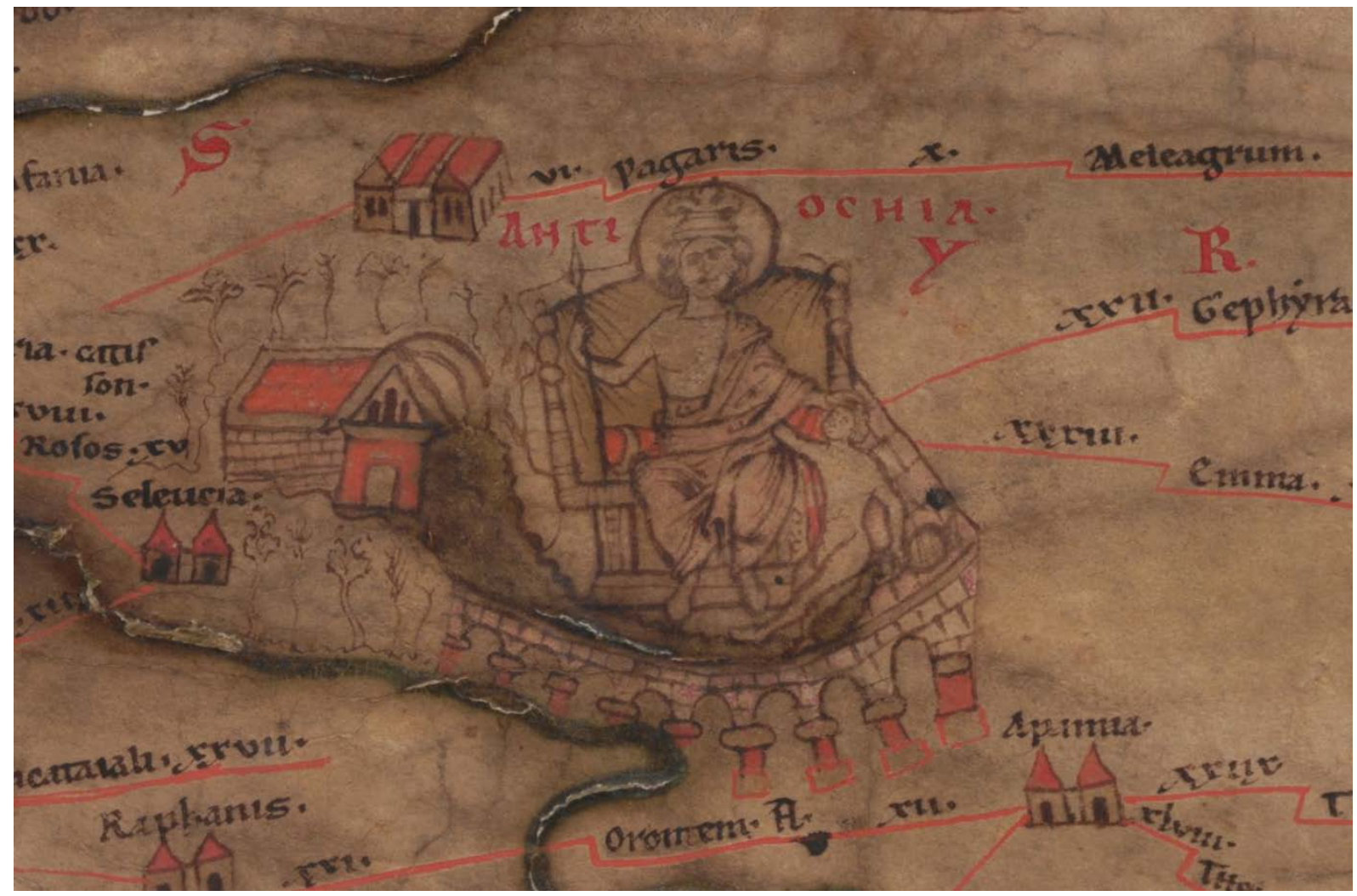

Fig. 2. Tabula Peutingeriana (Codex 324). Österreichische Nationalbibliothek. Used with permission.

Another intriguing similarity between De Excidio and late antique Antioch stems from Pseudo-Hegesippus' social-moral judgment. He avers that, at Daphne specifically, there exists a local populace that is numerous (frequens), very happy (laetior), and more refined (facetior) than any other 'Eastern' people, though nearer to licentiousness (sed propior lasciuiae). Depending upon Pseudo-Hegesippus' brand of Christian morality, any city of real size within the ancient Mediterranean might have fit this bill. However, among the limited physical remains that exist from late ancient Antioch, one particular specimen of material culture - arguably representative of late antique Antioch's upper echelons more broadly-bears striking resemblance to De Excidio's moralistic distinction. I refer to the center panel of the mosaic floor within the Atrium House triclinium (Fig. 3), where we also find the famous Judgment of Paris mosaic. ${ }^{38}$ Becker and Kondoleon describe the work:

The Drinking Contest Between Herakles and Dionysos, rarely depicted in ancient art, represents the god of wine turning over his empty cup to show he is the victor. Dionysos reclines upon a long green cushion and rests his elbow on a tall white cushion. Herakles, in contrast, seems tipsy as he leans backward on his knees, grabs at the drapery around his legs, and lifts the wine cup to his lips. At the left side of the scene, complementing the flanking satyr and maenad, a female plays a double flute into Herakles' ear. Eros rushes with outstretched hands toward Dionysos as if to applaud the winner. Silenos with white hair and a beard sits behind Dionysos and raises his right arm in a triumphant gesture. ${ }^{39}$

${ }^{38}$ See Becker, Kondoleon, NeWman, WyPyski 2005, p. 17-80.

${ }^{39}$ BeCKer, KondoleOn, NeWMAn, WyPysKi 2005, p. 22-23. See further discussions at p. 27-28. Dionysus also appears in other mosaics at Antioch, for example one from CE 350-400; see on this MOLHOLT 2005, p. 190195. Drinking, Dionysus, and other such 'lascivious' activities would have been much more commonly por- 


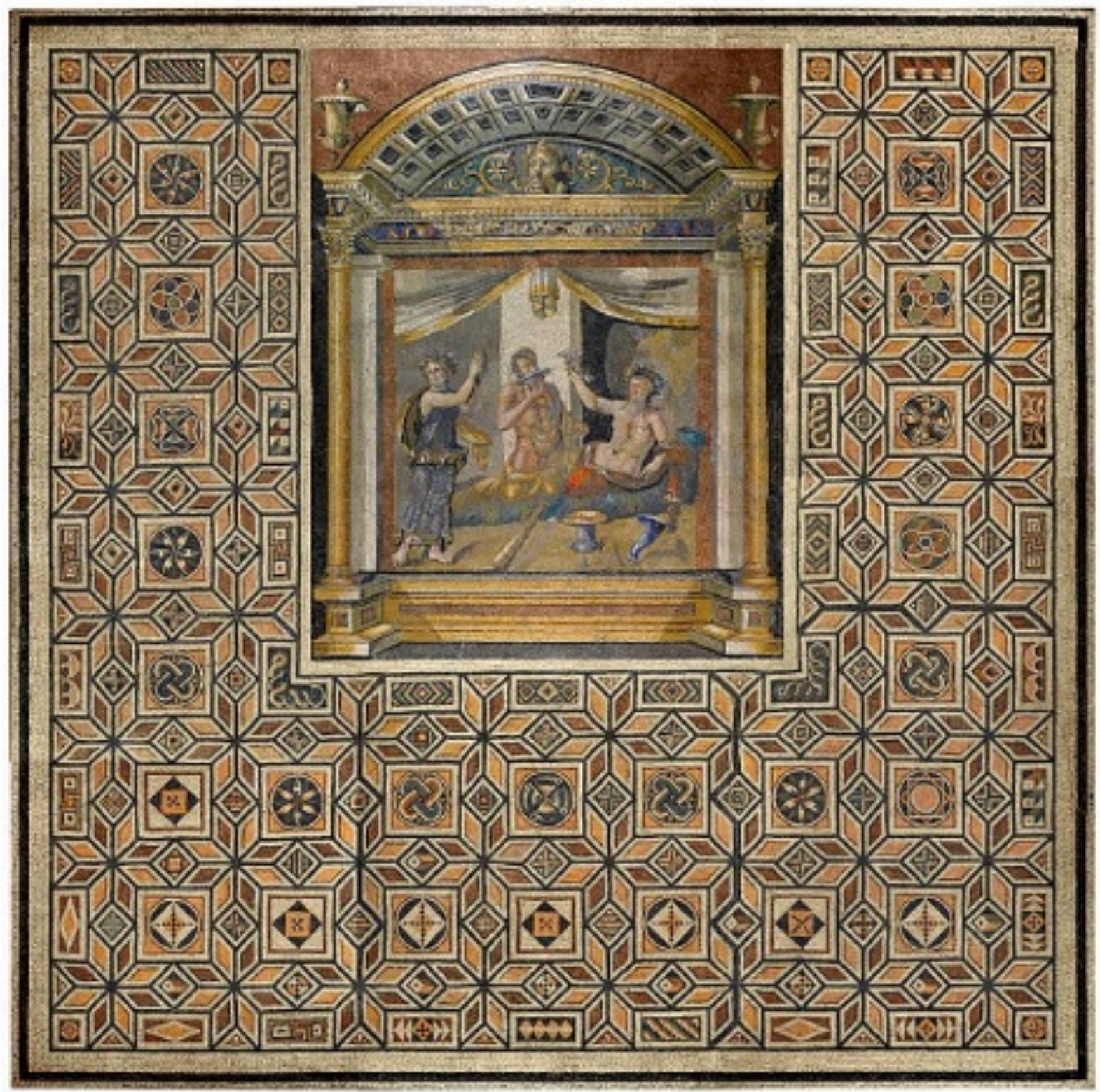

Fig. 3. Public Domain. The Drinking Contest of Dionysos and Herakles. Princeton University Art Museum.

Excessive drinking, drunken nudity, ${ }^{40}$ 'pagan' gods: ${ }^{41}$ this very usual scene of antiquity seems just the kind of household artwork that could lead a Christian commentator of the late

trayed in ancient Antioch than the few remains suggest, and even within those these themes are common. See again the nude Statue of Dionysus from the House of Menander at Daphne, whose "long hair, casually inviting pose and loose drapery all add to the sexual innuendo of this figure (BECKER, KONDOLEON, NEWMAN, WYPYSKI 2005, p. 253-254).

${ }^{40}$ On the idea that the "new cultural concerns and social values" associated with Christianity shifted practices of nudity and its presentation in late antiquity see "Nudity" in BOWERSOCK, BROWN, GRABAR 1999, p. 615-616.

${ }^{41}$ Christian responses to and (in)tolerance of Roman gods as represented via various media continues to constitute a debated point within scholarship, but suffice it to say that Christians were not "pro-pantheon" and that Antioch had, in late antiquity, an enormous corpus of divinities within its art and architecture, at that point on its 
ancient world to indignant hyperbole. ${ }^{42}$ Dining-room mosaics such as these were the quintessential self-expressions of the refinement of elites, and were conspicuously present in Antioch, where the "owners and inhabitants of these houses were interested in demonstrating their paideia or culture." ${ }^{\text {" If }}$ If take this Drinking Contest scene to be one of many cultural presentations of Antioch in the Roman Imperial Period, ${ }^{44}$ it is easy to imagine the author of $D e$ Excidio speaking of Antioch as an incredulous insider. Pseudo-Hegesippus highlights the happiness, ${ }^{45}$ the refinement, ${ }^{46}$ and the excess of late ancient Antiochenes, and the material culture of the city tends to highlight the exact same things. Once again, Pseudo-Hegesippus had Antioch pegged.

Other apparent 'Antiochene ties' exist in De Excidio's long description of the city. One which Bell points out is the version of the story regarding the mime actor and the arrival of the invading Persians in CE 260. A similar version of this story is found in Ammianus 23.5.3: $:^{47}$

For once upon a time at Antioch, amid deep silence, an actor of mimes, who with his wife had been presented in stage-plays, was presenting some scenes from everyday life. And while all the people were amazed at the charm of the performance, the wife suddenly cried: "Is it a dream, or are the Persians here?" Whereupon all the people turned their heads about and then fled in all directions, to avoid the arrows that were showered upon them from the citadel. Thus the city was set on fire, and many people who were carelessly wandering about, as in time of peace, were butchered; neighboring places were burned and devastated, and the enemy, laden with plunder, returned home without the loss of a single man. Mareades, who had inconsiderately brought the Persians there to the destruction of his own people, was burned alive. This took place in the time of Gallienus. ${ }^{48}$

way to being replaced by the Christian replacements springing up in the wake. See, in general, BECKER, KONDOLEON, NEWMAN, WYPYSKI 2005.

${ }^{42}$ E.g., centuries earlier we find a pointed criticism of pagan idolatry from an Antiochene Christian in Theophilus of Antioch Ad Autolycum 8-11.

${ }^{43}$ Beck BeCKer, KondoleOn, NeWMan, WyPYSKi 2005, p. 29.

${ }^{44}$ The triclinium likely date to the mid-third century CE, on which see discussion in DUNBABIN 1999, p. 162 (esp. n. 7).

${ }^{45}$ Frivolity and happiness might be read from the mosaic above, and contingently from other evidence. We do have a potential game piece, e.g., from Antioch (WINDHAM 2005, p. 273). Antioch was known as a host of the Olympic games in late antiquity as well; see LIEBESCHUETZ 1972, p. 136-144; DownEY 1939, p. 428-438. Maxwell has noted the significance of this Olympic theatre at Daphne (built by Hadrian), and further notes that "[s]ome scholars, influenced by the writings of Ammianus and others on this subject, have described a particular love of entertainment as characteristic of Antioch;" MAXWELL 2006, p. 55; could Pseudo-Hegesippus have had something like this in mind when employing the adjective laetior?

${ }^{46}$ This is suggested by the mosaics and triclinia found at Antioch, as by a host of other cultured material remains; see, e.g., the jewelry and personal adornments in WINDHAM 2005; also the engraved silver plate from the $4^{\text {th }}$ century CE, which actually had the word "MAKAR[IOU]" inscribed upon it (BECKER, KONDOLEON, NEWMAN, WYPYSKI 2005, p. 255-256). Note also the genteel mosaic of the time of De Excidio in MOLHOLT 2005, p. 196-207.

${ }^{47}$ Bell states that while "[o]ther sources mention the attack ... only Hegesippus and Ammianus relate this particular dramatic version" (BELL 1977, p. 28 [emphasis added]). On the difference in vocabulary between the accounts of Pseudo-Hegesippus and Ammianus, Bell argues that "one can reasonably argue that two natives of the same city have chanced to mention a disaster which had befallen their home a century earlier" (p. 29).

${ }^{48}$ Namque, cum Antiochiae in alto silentio, scaenicis ludis mimus cum uxore immissus, e medio sumpta quaedam imitaretur, populo venestrate attonito, coniunx 'Nisi somnus est,' inquit, 'in Persae, ' et retortis plebs 
This narrative does resemble the version in De Excidio, and this is not the only place in which these two authors overlap in their writing about Antioch. Since Ammianus Marcellinus most likely hailed from Antioch, ${ }^{49}$ the fact that these authors relate similar traditions, and more than once, ${ }^{50}$ may be read as circumstantial evidence that the two were natives of the same city.

A last note to be made about De Excidio's Antiochene topography concerns the Orontes River. Bell notes Karl Mras' earlier incredulity that anyone familiar with Antioch could give the name Orientem to a river that should have been dubbed Orontem. ${ }^{51}$ Bell argues contrawise that this passage "which Mras takes as certain proof that the author is not a Syrian ... actually is only one more indication that he is. ${ }^{, 52}$ Bell recounts how Strabo records numerous names for the river, ${ }^{53}$ how John Malalas routinely calls it Orentes, ${ }^{54}$ and cites several $9^{\text {th }}$ - or $10^{\text {th }}$ century manuscripts of Cassiodorus' Historia Ecclesiastica Tripartita that refer either to in Oriente flumine or in Orente flumine. ${ }^{55} \mathrm{He}$ finally concludes that "Hegesippus' reference to Antioch's river as the Orientes is by no means unique, nor does it imply lack of familiarity with that part of the world." ${ }^{56}$ While predominantly apophatic-Bell effectively posits that Pseudo-Hegesippus was not necessarily not from Antioch-Bell's argument for an Antiochene identity for the author of De Excidio lines up with the pieces of topographic evidence present within the text.

universa cervicibus, ex arce volantia in se tela delinans, spargitur passim. Ita civitate incensa, et obtruncatis pluribus, qui pacis more palabantur effusius, incensisque locis finitimis et vastatis, onusti praeda hostes ad sua remearunt innoxii, Mareade vivo exusto, qui eos ad suorum interitum civium duxerat inconsulte. Et haec quidem Gallieni temporibus evenerunt. Text and translation from the Loeb; see RoLFE 1964.

49 See discussion, including of those who do not hold this view, in DEN BOEFT, DrIJVERS, DEN HENGST, TEITLER 2013, p. 97.

${ }^{50}$ Concerning how they relate these traditions, Bell argues that De Excidio's employment of the phrase denique ferunt denotes "a formula often used to introduce material derived from some general fund of knowledge" (BELL 1977, p. 29). He does not state what is of course the case; namely, that such a "general fund of knowledge" could arguably have been tapped from anywhere. See also Pseudo-Hegesippus' use of habetur at the very beginning of his description of Antioch above. Such language suggests, to my mind, neither that the author is likely to have come from Antioch, nor that he is likely not to have. It is normal third person language within ancient Latin prose, particularly prominent within historiography.

${ }^{51}$ USSANI, Mras 1960 [1932], vol. 2, p. xxxiii.

${ }^{52}$ BELL 1977, p. 29.

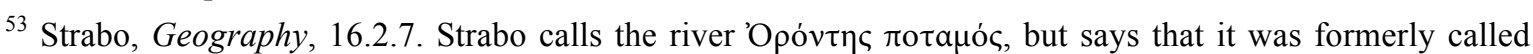

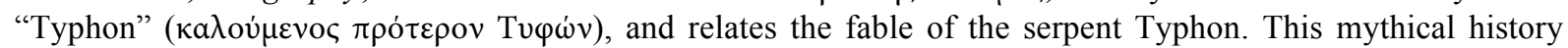
hardly supports Bell's argument, but does illustrate the plasticity of nomenclature in antiquity. Pausanius (Description of Greece 8.29.3) has the same name for the river as Strabo, and also references a serpent logos.

54 John Malalas Chronicle 10.10.234; 10.20.245. Bell had reason to complain at the time of his writing about

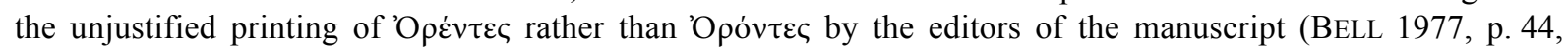
n. 106). The problems with the Greek text's transmission are related in BURY 1897, p. 219-230. Today, however, even English translations are faithful to the Greek, as in JEFFREYS, JEFFREYS, SCOTT 1986, p. 125: "Tiberius renamed the city's river, previously known as Drakon, to be Orentes in the Roman language." The work also survives in Slavonic; see SPINKA, DOWNEY 1940.

55 At 7.14.2; BELL 1977, p. 30, citing Codex Vesontionensis $\left(10^{\text {th }}-11^{\text {th }}\right.$ century) and Codex Vaticanus Palatinus $170\left(9^{\text {th }}-10^{\text {th }}\right.$ century).

${ }^{56}$ BELL 1977, p. 30. 


\section{Literal Biblical Interpretation at Antioch}

If diffidently, ${ }^{57}$ Bell offers further reasons for reading De Excidio as a text from Antioch: he suggests that its being from Antioch would make sense of its overtly literal approach to biblical interpretation, as opposed to allegorical proclivities. Indeed, the biblical and extrabiblical subject matter the author claims to have treated in addition to De Excidio fits this bill, as does the language used in the Prologue:

Quattuor libros Regnorum quos scriptura complexa est sacra, etiam ipse stilo persecutus usque ad captiuitatem Iudaeorum murique excidium et Babylonis triumphos historiae in morem composui. Macchabaeorum quoque res gestas propheticus sermo paucis absoluit. ${ }^{58}$

Bell is right in positing that the environment that produced the "literal school" of historical exegesis-Antioch - is "the very sort of atmosphere that one would expect to produce a reworking of the four books [of Kingdoms] historiae in morem," and the res gestae of the Maccabees as well. ${ }^{59}$ Antioch was known in late antiquity for its literal exegesis - and its interest in 'historical readings' - and was sometimes faulted for it. ${ }^{60}$ Its biblical exegetes had little time for typology and allegory. ${ }^{61}$ Since this is the only kind of biblical tradition De Excidio seems overtly to have engaged, it would indeed fit were its author from Antioch. ${ }^{62}$

\section{Maccabean Martyrs at Antioch}

Another perceptive note Bell makes is that De Excidio (5.22) includes a lengthy account of the Maccabean martyrs of 4 Maccabees, found nowhere in Josephus. Bell muses: "it is interesting to note that the seven brothers and their mother enjoyed virtual sainthood in Antioch, among Christians as well as among Jews." ${ }^{63}$ It is true that in late antiquity some traditions held Antioch as the burial place of the Maccabean martyrs, ${ }^{64}$ and that Matrona's Cave in Daphne, where these martyrs were venerated, was likely not the only site in late antique Antioch where this was done. ${ }^{65}$ Antioch and the Maccabean martyrs were closely connected ${ }^{66}$-an

\footnotetext{
${ }^{57}$ Bell puts it thus: "Once one admits the likelihood that the author is at least from Antioch ... a few things in the text take on a new meaning" (BELL 1977, p. 32).

${ }^{58}$ De Excidio Prologue 1.

${ }^{59}$ BELL 1977, p. 32.

${ }^{60}$ For example, the Antiochene school's treatment of the Psalms was thought by some to be problematic, not least due to its effect on Christology; see O'KEEFE 2000; and see the scholarship surveyed in Nassif Bradley, "Spiritual Exegesis in the School of Antioch," in BRADLEY 1996, p. 343-377.

${ }^{61}$ Young 1997, p. 162.

${ }^{62}$ Indeed, in certain regards De Excidio could be seen to be engaging in the precise practice of $\theta \varepsilon \omega$ pia for which Antiochene exegesis was known. See the longstanding scholarly discussion in, e.g., WALLACE-HADRILL 1982, p. 32-33; TERNANT 1953, p. 135-158; VACCARI 1920, p. 3-36; KIHN 1889, p. 531-582.

${ }^{63}$ Bell 1977, 32-33. He cites ObermanN 1931, p. 250-262; MAAS 1900, p. 145-156; JerEmias 1941, p. 254-255.

${ }^{64}$ Augustine Sermon 300.6 (PL 38.1379), who mentions in this regard a basilica at Antioch built in their honor, and in Sermones 300 and 301 discusses the tensions between Christians and Jews competing for 'ownership' of these heroes and their traditions at Antioch; see RouWHORST 2005, p. 81-96. Bell also cites Jerome De situ et nominibus locorum hebraicorum.

${ }^{65}$ See the argument in VINSON 1994, p. 166-192. The problem, for those like John Chrysostom, was that these 'Jewish' martyrs were also venerated by Christians. But it was Gregory of Nazianzus who established a Maccabean martyr cult in Antioch. See discussion in SIZGORICH 2009, p. 47. It is also interesting that, as Bell suggests that De Excidio was written around the time of and partially in response to Julian's abortive attempt to
} 
Antiochene author might very well insert into his historical narrative an account of the Maccabean martyrs so revered in his home town. De Excidio, in fact, makes several notable mentions of the Maccabean martyrs, and at 5.2 connects their heroic actions explicitly to Antioch. $^{67}$

It would be particularly unsurprising to find an Antiochene author tapping the Maccabean martyr tradition within a work aimed in some way against Jews, Jewish practice, or Judaizing amongst Christians. ${ }^{68}$ In this regard, De Excidio fits with Antioch in more ways than one: inasmuch as Antioch was a locus of Maccabean fame and a place of considerable anti-Jewish Christian activity, De Excidio's combination of these motifs fits perfectly with Antiochene authorship. Once again, Bell's suggestion seems eminently reasonable upon reflection. Next, I adduce several datapoints which Bell does not mention, but which correspond nicely with the suggestion that De Excidio or at least its author came from Antioch.

\section{Peter and Paul at Antioch}

One of the most striking features of De Excidio's narrative is its insertion of a Christian apocryphal legend into its narrative. At 3.2, Pseudo-Hegesippus relates how Peter and Paul, as well as the nefarious Simon Magus, were at Rome when a favorite courtesan of Nero's died. Peter and Simon Magus are put forward as individuals who might be of help in this matter, and when both are summoned a 'contest of resurrection' ensues. Peter allows Simon first to try reviving the dead man, and Simon ups the ante with a bet: if he should succeed in resurrecting the man, Peter will be put to death. Peter agrees, and Simon effects a kind of halfrevivification. ${ }^{69}$ Peter exposes the farce by separating Simon from the corpse, then resurrects the man himself, yet prevents an eager crowd from stoning Simon as an impostor. His pride injured, Simon proclaims that on a certain day he will ascend the Capitoline Hill, throw himself off, and fly; and perhaps to the reader's surprise, he does just this. People begin to call Simon divine given his ability, at which point Peter, fed up, prays that Simon immediately fall to the ground, but to injury and not to death. This is exactly what happens, and Simon leaves in disgrace. Thereafter Peter is arrested and must be convinced by his brethren to leave the

rebuild the Jerusalem Temple, it may also be that the growth of Christian traditions regarding the Maccabean martyr cult at Antioch developed during the reign of Julian and perhaps in response to his policies regarding Christians; see MAYER 2003, p. 116.

${ }^{66}$ Most recently, see KRAUTHEIM 2018, p. 189ff (noting bibliography and earlier chapters on Antioch generally).

${ }^{67}$ At 5.2.1, amidst a speech that is at once lament and chastisement of the Jewish people for how far they have fallen from their pious predecessors like Abraham, Joshua, and David, the author inserts this poignant rhetorical question: "Where is that faith of the Maccabees, which once upon a time extraordinarily overthrew the Babylonians, which put the Persians to flight, which turned the tables on Demetrius, which at the last among the children and women of Antioch overcame arms, swords, and fire and, out of respect for the nation's customs, preferred to be killed rather than to comply with imperial commands?" (Vbi est illa Macchabaeorum fides, quae quondam in paucis fudit Babylonios, Persas fugauit, Demetrium perculit, ad postremum in paruulis et mulieribus Antiochi arma gladios incendiaque superauit et pro obseruatione patria mori maluit quam regis imperiis obtemperare?).

${ }^{68}$ This is exactly what the text of De Excidio is doing, as recognized in the summary treatments of INOWLOCKI 2016, p. 356-67, and KLETTER 2016, p. 368-381. See further, on specific sermons that John Chrysostom preached in response to this 'Maccabean crisis,' JOSLYN-SIEMIATKOSKI 2009, p. 42ff.

${ }^{69}$ This zombie-evoking scene is similar to Heliodorus Aethiopica 6.14-15; Bowersock compares other, related tales of Peter - those of the Pseudo-Clementines - with Heliodorus' Aethiopica in BowERSOCK 1994, p. $140 \mathrm{ff}$. 
city. While leaving, in an early iteration of the Quo Vadis mini-narrative, Peter meets Christ and recognizes his date with destiny. Thereafter Peter is crucified, upside down, along with Paul. $^{70}$ This appears as a chronologically parallel historical episode alongside events of the Jewish War.

What is important here are not the details of this episode, but rather the fact that, of all the Christian narrative traditions which Pseudo-Hegesippus could have inserted into De Excidio, he opts for one that forefronts both Peter and Paul. Granted, these are two of the most popular figures within early Christian legend. Likewise, such a narrative could have emerged anywhere, and particularly in Rome. But in the present argumentative context it is worthwhile to point out that Peter and Paul held special places of veneration at late antique Antioch as well. $^{71}$ The Grotto of St. Peter (Fig. 4), now a church and pilgrimage site, may testify to early Christian veneration of the saint in Antioch; it lay at a prominent place in the city near a crossroads by the Jewish Quarter, the Forum of Valens, and the famous Charonion. ${ }^{72}$ Paul was also apparently represented on ancient Antioch's physical landscape: Theodoret mentions a cave at the foot of the Antiochene mountain associated with the apostle, ${ }^{73}$ and the apocryphal Paul and Thecla tradition was also represented within Antioch's architecture in antiquity. ${ }^{74}$ Peter and Paul both have ties to late ancient Antioch, and both are included in the narrative of De Excidio.

While Peter and Paul enjoyed wide popularity in late ancient Christian tradition, they both had particularly early ties to Antioch. This is witnessed by the traditions in the New Testament texts of Acts $(11,13-15,18)$, Galatians $(2: 1-12)$, and 2 Timothy (3:11). ${ }^{75}$ Moreover, noteworthy is Tappenden's statement that "most of the New Testament sites associated with Peter (e.g., Galilee, Jerusalem, Caesarea) do not seem to have retained or produced any form of localized Petrine traditions/memories; the only exceptions are Syria and Rome." therefore, was an apt locale for fostering Petrine and Pauline textual traditions, in this regard as apt as Rome.

\footnotetext{
${ }^{70}$ Cf. 1 Clement 5:4-7; see discussion in Brown, MEIER 1983, p. 124.

${ }^{71}$ See the summary at Brown, MEIER 1983, p. 85, who conclude that the Peter and Paul traditions were already firmly established very early in Christian history.

${ }^{72}$ The antiquity of the Peter tradition associated with this place is contested, and "could easily have been a pre-Christian site of worship, since it contains a spring and hand an early Roman mosaic floor;" attributed to Wendy Mayer by SHEPARDSON 2014, p. 167, n. 18. Legends vary in plausibility, and include the tradition that the now church is built on property which belonged to Luke the Evangelist, but suffice to say that a strong Peter tradition existed in Antioch probably very early, as attested also in New Testament texts. See FANT, REDDISH 2003, p. 149-150. These early traditions' most prominent contemporary permutations may be found on the web site of the Antiochian Orthodox Christian Archdiocese of North America (antiochian.org). The fact that neither John Malalas nor Egeria mention this Cave/Church of St. Peter may suggest that it emerged later. See further CHRISTENSEN-ERNST 2012, p. 24.

${ }^{73}$ Historia Religiosa 2.18; mentioned by SHEPARDSON 2014, p. 20. Theodoret also connects Peter and Paul to Antioch as early influences there at Historia Ecclesiastica 3.22. See in addition the place identified as "Paulos of the Christians," a church of potential antiquity, recorded by Pietro della Valle in 1625 as presented in DEGIORGI 2016, p. 1 .

${ }^{74}$ See W KLEINBAUER 1973, p. 89-114.

${ }^{75}$ See historical and chronological discussion in, e.g., DOWNEY 1963, p. 125-126.

${ }^{76}$ TAPPENDEN 2014, p. 278; in agreement with BOCKMUEHL 2010, p. 77.
} 


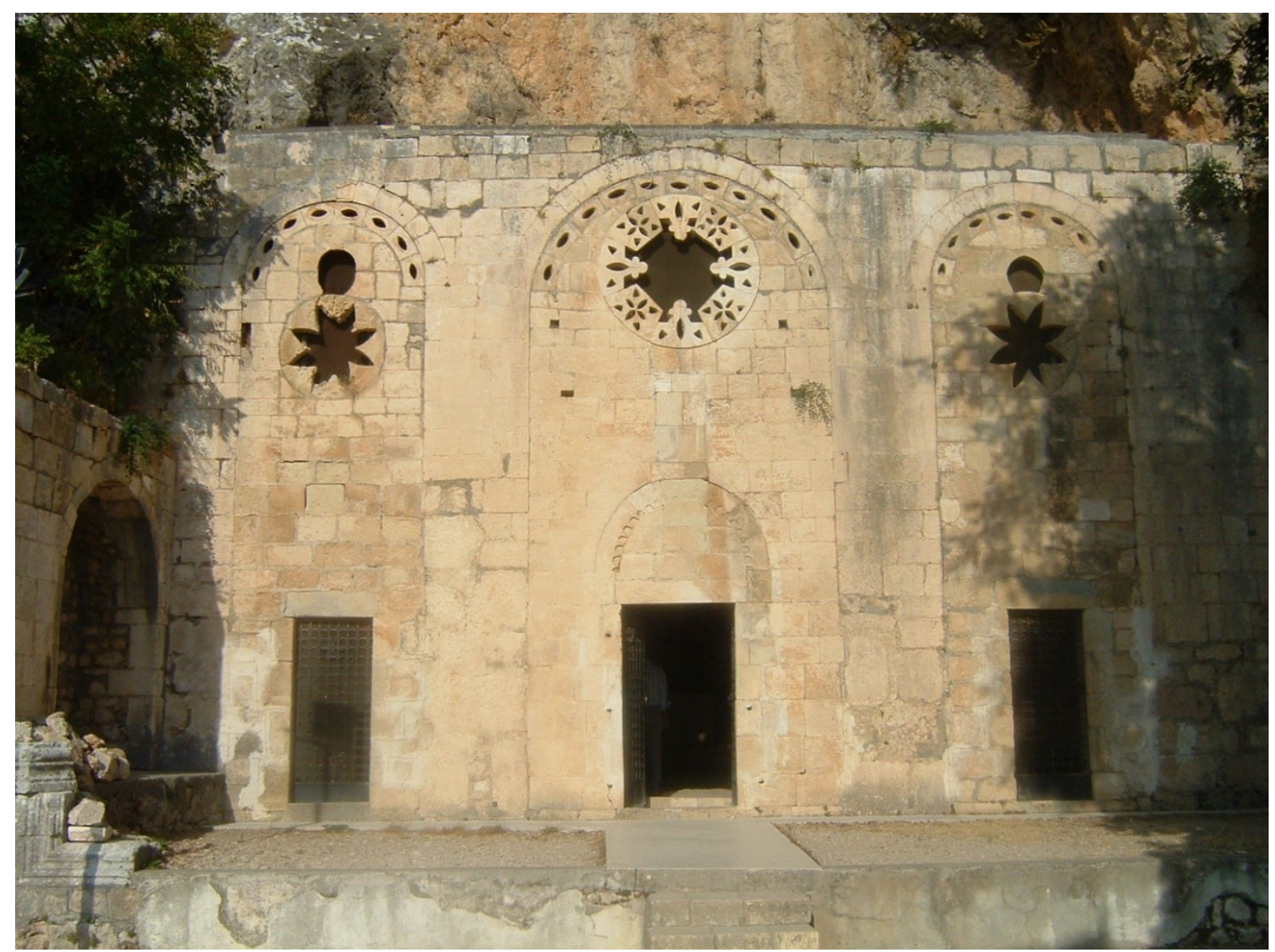

Fig. 4. The Grotto of St. Peter today at Antioch (Antakya). (C) Andrea DeGiorgi. Used with permission

\section{Latin Language at Antioch}

One tacit reason which scholars may have to associate De Excidio with Rome, even if the text were not associated with Ambrose, is that it was written in Latin. Rome, after all, was the home of the Latin language. Latin long functioned as the administrative language of the Western Empire, and in the fourth century the ability of diplomats from both East and West to function bilingually was diminishing. ${ }^{77}$ One might thus assume that it would have been altogether unlikely for a Latin text to have been written at Antioch or by someone from Antioch. In late antiquity, Antioch is generally understood to have been a linguistic crossroads of Greek and Syriac, but not of Latin. Yet there are other factors to consider. First, Antioch had longstanding military demographics. Writing on Ammianus Marcellinus, David Rohrbacher states:

In the Antioch of his youth, Latin would have been a familiar language. The emperor Constantius II used Antioch as his base during a series of wars against the Persian empire throughout the 340s, and the city was filled with Latin-speaking soldiers and bureaucrats. ${ }^{78}$

Perhaps Ammianus grew up in a military family, perhaps in a Latin-speaking home. It is not out of the question that the author of De Excidio did likewise - it is intriguing to imagine

\footnotetext{
77 Thus, e.g., Justinian's Code eventually needed to be translated into Greek; HOLWERDA 1962, p. 274-292; see further discussion in CAMERON 2009, p. 15-36.

${ }^{78}$ ROHRBACHER 2002, p. 14.
} 
such a context for the author of the first military history known to have been written by a Christian. ${ }^{79}$ Latin would have been known at Antioch due to military influence if nothing else; it would have constituted a linguistic sine qua non of any kind of administrative career there. ${ }^{80}$ But Latin seems to have been used in educational and cultural contexts as well. ${ }^{81} \mathrm{Li}$ banius thought enough of Latin — or, rather, little enough of it - to blame that language, along with Roman law, for the decline of his own school of Greek rhetoric. ${ }^{82}$ Latin seems, then, to have been somewhat of a cultural force in late antique Antioch. ${ }^{83}$ It also would have existed on epigraphy and architecture in Antioch, beginning hundreds of years before the fourth century. Latin also, of course, would have functioned as the lingua franca for merchants who did business in the west or with westerners, as evidenced by a bilingual (Greek/Latin) monument at Lyons erected for a Syrian tradesman (negotiator Luguduni) named Thaemus Iulianus (Fig. 5). ${ }^{84}$ Even if it was largely restricted to administrative and legal use, Latin had enough of ${ }^{79}$ And there is reason to believe that Latin was associated specifically with military history (i.e. classical his-
toriography) in late antiquity, at least in Jewish thought: "Rabbi Jonathan of Eleutheropolis said: "Four languages
are appropriately used in the world. And these are: Greek for song, Latin for war, Syriac (Aramaic) for mourn-
ing, Hebrew for speaking."' y. Megilla I $71 \mathrm{~b}$, col. 748 as cited and discussed in ISAAC 2009, p. 43. See further
Isaac's conclusions on p. $66-67$.
${ }^{80}$ ADAMS 2003 , p. 688 , n. 3 ; Hall points out that Cicero and Vergil in particular served as means of career
advancement and ethnic identity formation in the Greek East; HALL 1999, p. 85; however, Hall remarks that
even if "Latin was an entrée to promotion in the Later Roman Empire," it still "remained an elite language
whose use was almost entirely confined in the East to the courtroom, the army, and the court ... to be conscien-
tiously studied and mastered by ambitious young men who saw what such knowledge could do for their careers"
(p. $89-90$ ). This may have been the case, but perhaps not (see discussion below). We do know that a hearing
before Caracalla at Antioch in CE 216 was undertaken in Greek, but recorded in Latin; see ADAMs 2003 , p. 383 , 391.

${ }^{81}$ Not that "administrative" and "educational" and "cultural" comprised hermetically sealed spheres of activity in late antiquity, or at any other time. Education and imperial careers were nearly always linked; John Chrysostom (Adversus oppugnatores vitae monasticae 3.5; PG 47.357) remarks how some unknown person of low circumstances realized substantial social mobility, "having procure for himself the power of words: ó $\delta \varepsilon \tilde{v} \alpha$,

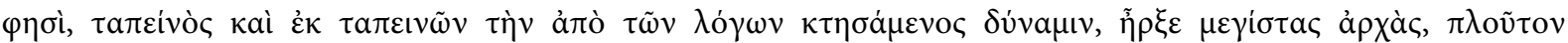

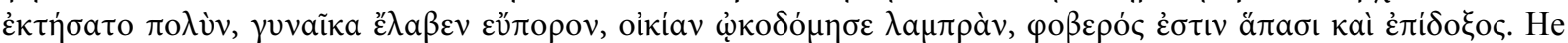
goes on to note a parallel case where learning the "language of the Italians" led to a "brilliant" career in imperial

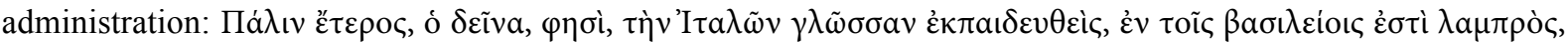

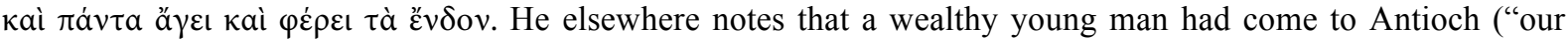

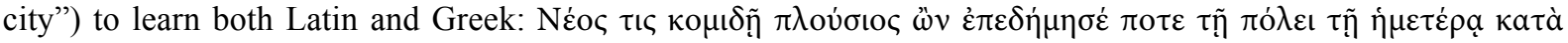

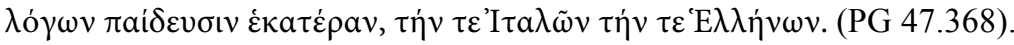

${ }^{82}$ Libanius Autobiography 234: "Moreover, as regards my studies, they had now lost ground to Latin even more than before, so that I am afraid that they may, through the agency of law, become completely superseded. Yet it is not law or edicts that have brought this about, but the honour and power reserved for those acquainted with Latin. However, the gods have granted this eloquence, and will in the end ensure that what they

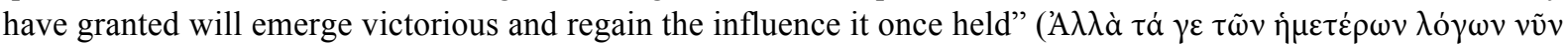

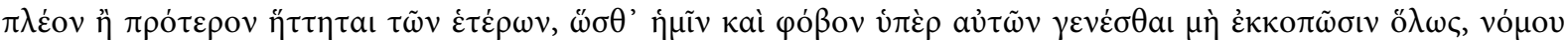

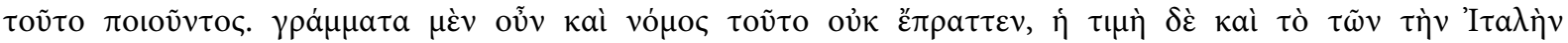

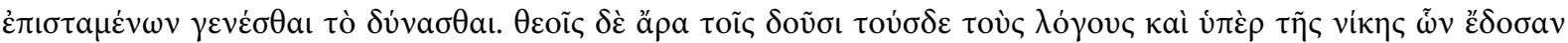

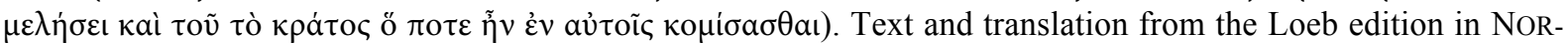
MAN 1992, p. 290-291. Perhaps this hit close to home for Libanius because his great-grandfather knew Latin so well that it was thought that he came from Italy (NORMAN 1992, p. 3 ).

${ }^{83}$ Note Eck's statement that “...Greek and Latin ... in many places 'competed' with each other for dominance in the public sphere." ECK 2009, p. 17.

${ }^{84}$ DIIS MANIBVS | THAEMI IVLIANI SATI []L SYRI | DE VICO ATHELANI DECVRION[]| []EPTIMIANO CANOTHA NEGO | TIATORI LVGVDVNI ET PROV | AQVITANACICA AVIDIVS | AGRIPPA FRATRI PIENTISSI | MO OB MEMORIAM EIVS | FACIENDVM CVRAVIT ET | SVB ASCIA DEDI- 
a presence in late antique Antioch that it does not stretch the imagination to conceive of a history having been written in Latin at Antioch, or at least by an Antiochene. ${ }^{85}$ And it is by no means certain that Latin was so restricted in late antiquity; Joseph Geiger has made a convincing case that Latin was very much a live literary language in late ancient Antioch, and a great many of his supporting examples are Christian authors. ${ }^{86}$

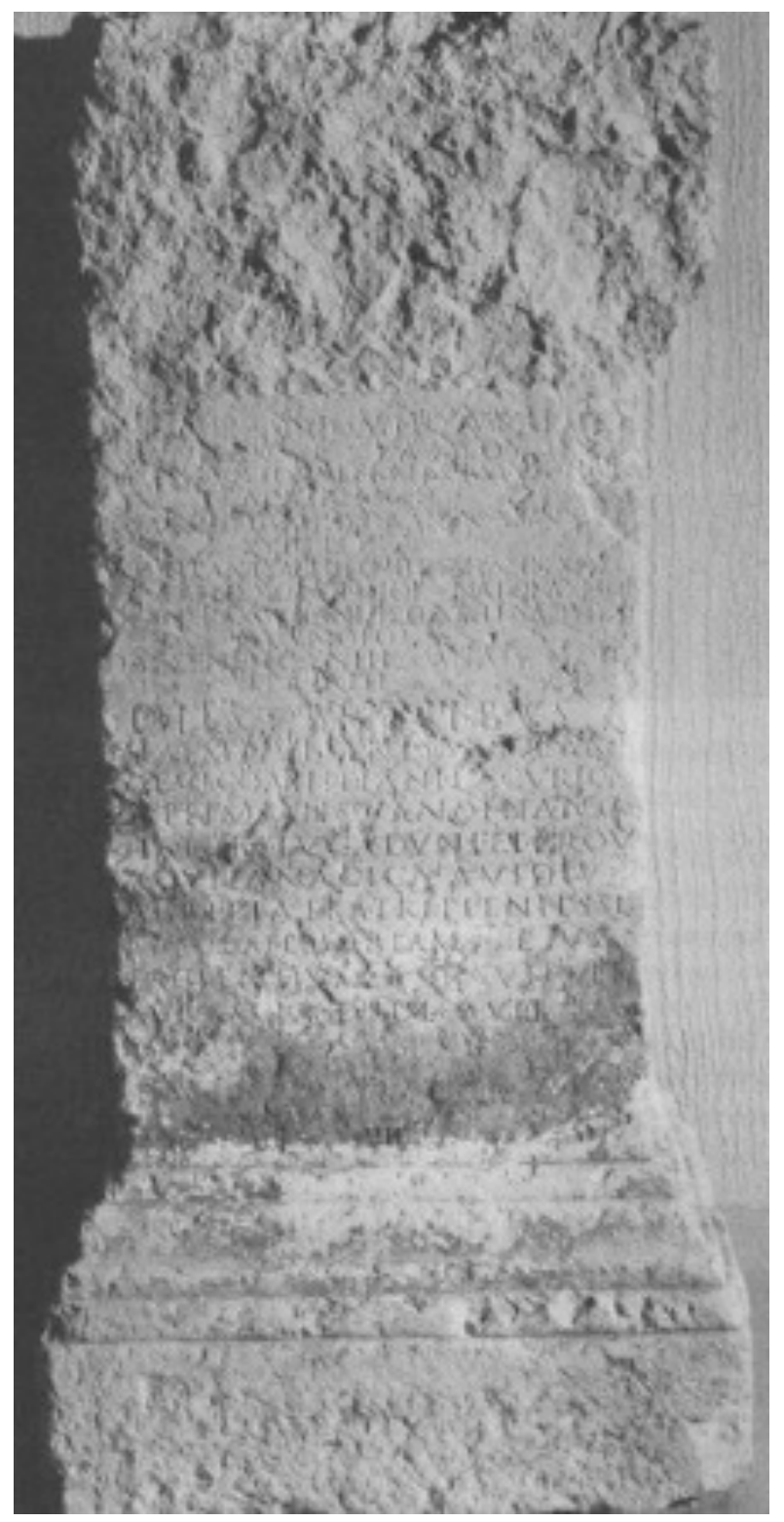

Fig. 5. Epigraphik-Datenbank (EDCS). Used with permission.

CAVIT. Erected by his brother Avidius Agrippa, and dated to the late second century; CIL XIII.2448/ILS 7529/IG XIV.2532/IGR I.25. See comparable epitaphs in WIERSCHOWSKI 1995, p. 124; see also p. 148 . The epitaph states that "the inevitable hand of fate caused him to die in a foreign land;" see CARROLL 2006, p. 152.

${ }^{85}$ That this is at least plausible, see discussion in GEIGER 1999, p. 608, n. 15 ; p. 610, n. 37, p. 612-617; see also MATTHEWs 1994, p. 152-169.

${ }^{86}$ GEIGER 1999, esp. p. 614-615. 


\section{Xenodocheia at Antioch}

As another piece of supplementary evidence, I mention another intriguing connection between De Excidio and Antioch. Mark Anderson has recently pointed out what he calls a "mistranslation" of Josephus that is present in both De Excidio and Josephus' Latin translator Rufinus. ${ }^{87}$ Josephus records at Judean War 1.61 that John Hyrcanus was the first among the Jews to institute the practice of hiring foreigners - that is, of xenotrophein. ${ }^{88}$ At 1.1.8, De Excidio renders this term in a translation that Anderson argues betrays a misunderstanding of the Greek, or rather which signals an institution that was only coming into vogue in the fourthcentury, the institution of xenodochia ${ }^{89}$ This was a system by means of which wanderers and the poor were provided with food and shelter, ${ }^{90}$ and is of course unrelated to Josephus' term xenotrophein. I find it interesting that, as Anderson also notes, "the first philanthropic xenodochia on record were said to be functioning in Antioch in about the year 350." 91 Perhaps the author of De Excidio - probably written only a few decades after 350 - came from Antioch and for that reason associated the idea of xenodochia, a nascent institution at the time, with the more arcane xenotrophein of Josephus' Greek in his adaptation of the Judean War.

\section{Christian-Jewish relations at Antioch}

A final note which I would make in brief regards Jewish-Christian relations as they existed at Antioch in late antiquity, in the fourth century in particular. De Excidio is a piece of classical historiography written from a Christian perspective with the express purpose of rewriting Jewish history and reinterpreting the Second Temple's destruction as a means of Jewish (and, by proxy, Christian) identity formation. ${ }^{92}$ Antioch was arguably the hotbed of JewishChristian debate, tension, and interaction in the late fourth century. John Chrysostom's famous Sermons Against the Judaizers are only one literary manifestation of this polemical

${ }^{87}$ ANDERSON 2017, p. 139-161. For De Excidio, however, "translation" was not the point of the exercise.

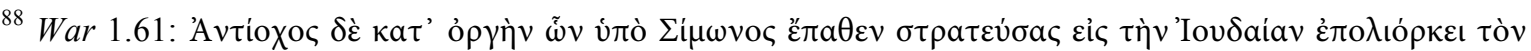
'

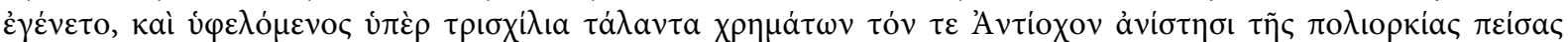

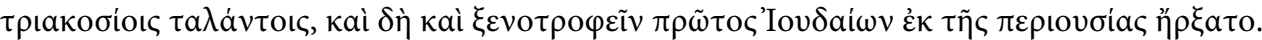

${ }^{89}$ De Excidio 1.1.8: Nec Antiochus quieuit qui Simoni patri Ionathae ludibrio suos fuisse exercitus indignabatur, cupiensque adsurgentes adhuc Ionathae primitias extinguere, cum magna ueniens manu, Hierosolyma Hyrcanumque obsedit. Reppulit Hyrcanus auro, quem ferro nequibat, reseratoque, ut Iosephus auctor est, Dauid sepulchro tria milia auri talenta eruit, ex quibus trecenta adnumerauit Antiocho, ut obsidionem relinqueret, pretio emtus abiret. Atque ut facti inuidiam leuaret, fertur ea pecunia Hyrcanus instituisse primus xenodochia, quibus aduentum susciperet pauperum peregrinorum.

${ }^{90}$ See discussion (which notes make Antiochene connections) in HAHN 2006; MILLER 2013. Such institutions were also connected to the imperial apparatus, especially in later antiquity; see SCHOOLMAN 2010, p. 98; on the institution's spread, see HORDEN 2005, p. 361-389.

${ }^{91}$ ANDERSON 2017, p. 154. However, Mark Anderson notes that, according to Theophanes of Constantinople, "Constantine I provided free grain for the poor in the xenodocheia of Antioch during the famine of 331-332 CE." ANDERSON 2012, p. 40. We may also note that religious argument materialized with specific reference to the Emperor Julian and institutions like these when he censured Eleusis, bishop of Cyzicus, for building a xérotropheia with "materials taken from pagan temples" (ANDERSON 2012, p. 35). Julian, moreover, was thoroughly implicated in the food shortages and the bureaucratic response to need and poverty which fluctuated in Antioch throughout the fourth century.

92 See the forthcoming BAY 2018; this is certainly also visible in the work's reception, on which see POLLARD 2015, p. 65-100. 
trend that had many permutations. ${ }^{93}$ Jews and Christians, both of whom had substantial, active populations in fourth-century Antioch, ${ }^{94}$ competed and coalesced there as they did in few other places (if any). ${ }^{95}$ Given De Excidio's subject matter, Antioch as place of origin fits that work's rhetoric probably better than any other city of late antiquity.

That both Jewish and Christian cultures and literatures thrived in late antique (especially fourth-century) Antioch is nothing new to scholarship. ${ }^{96}$ Nor is it necessarily novel to posit that both Christian-Jewish relations and inter-Christian relations in fourth-century Antioch were often marked by the power dynamics of social posturing, combativeness, and volatility. ${ }^{97}$ John Chrysostom, in his Sermons Against the Judaizers and elsewhere, again constitutes only one example of this. Within the Christian fold, the Arian controversy boomed in Antioch throughout the mid-fourth century, rendering liturgical ritual and architectural landscape as sites for the inscribing of social-religious difference. ${ }^{98}$ Between Christians and Jews, the matter is complicated by the incongruous Christian response to Judaism: most scholars have read Chrysostom's vehement villainization of the Jews as solid evidence that a great many Christians considered Jewish (religious) practice to be an attractive and viable option. ${ }^{99}$ Jews had flourished in Antioch for centuries, ${ }^{100}$ and this was very often considered an existen-

${ }^{93}$ See WILKEN 1983; another Syrian permutation of this dynamic in a different generic guise exists in the hymns of Ephrem, on which see SHEPARDSON 2008.

${ }^{94}$ Respectively see HAHN 2004, p. 139-145 (Jews at Antioch) and p. 146-160 (Christians at Antioch); for religious conflict in late antique Antioch generally, see inclusively p. 121-90.

95 See further SANDWELL 2007; also interesting is Kalleres characterization of the city: "We should imagine a city pulsating with spiritual power. People who live in Antioch intuitively understand the city's diverse array of invisible forces capable of inflicting harm or offering healing..." KALLERES 2015, p. 31.

${ }^{96}$ See the section on "Religious Diversity in Fourth-Century Syria" in Chapter 5 of KELLEY 2006.

${ }^{97}$ This is also true of Christian contests with Hellenistic religiosity or 'paganism.' For example, the mobile location of the remains of St. Babylas was understood by both Christians and non-Christians to embody a clash of the spiritual powers existing on both sides of the religious map. The Emperor Julian "attributed the silence of the oracle [at Daphne] to the presence of the Saint's relics," for this reason removing his martyrium, and the destruction by fire of the Temple to Apollo at Daphne in 362 described by Ammianus Marcellinus (22.13.3) was understood by Christians to be "a sign of the victory of Christianity." Busine 2015, p. 10. See John Chrysostom De S. Babyla c. Iulianum 93; Theodoret Historia Ecclesiastica 3.11.4-5.

${ }^{98}$ See GwYNN 2010, p. 229-63. At p. 244, n. 56, Gwynn discusses how doctrinal creeds would have been probably the only way in which Christian groups differed in their baptismal rites; at p. 245, Gwynn mentions the still extant "remains of the church begun by Bishop Meletius in $c a .380$ to hold the relics of St. Babylas" which "symbolize the 'return of orthodoxy' that Meletius wished to proclaim." The octagonal Golden Church, "begun by Constantine and dedicated by Constantius in 341" (p. 244), would not have had an immediately internally divisive valence but certainly would have contributed to a growing, structured identity content between Christians and 'others' (like Jews).

${ }^{99}$ I.e., VAN DER HORST 2000, p. 228-238.

${ }^{100}$ For example, there had been there a Jewish magistrate in the late-second century (John Malalas Chronographia 290); the Emperor Caracalla was asked to adjudicate concerning a wealthy Jewish woman's bequest to the Jewish community at Antioch in CE 213 (Codex Juris Civilis 1.9.1). Even after the empire became "officially Christian" under Theodosius, the Jews of nearby Apamea built a synagogue in CE 391 (WILKEN 1983, p. 56), which was funded by wealthy Antiochene Jews as evidence by inscriptions on its floors (MEEKS, WILKEN 1978, p. 52-55). See also the witness of the Syrian Church Father Aphraat in NeUSNER 1986, p. 199-228. In summary, see HAHN 1996, p. 57-89, and KRAELING 1932, p. 130-160. Another factor that should be considered is the cultural alliances between Jews and others, natural and inevitable in a context of any kind of social interpenetration and diversity, such as those between Libanius and the Jewish patriarch Gamaliel. Such influence would have made Jewishness all the more a threat to a Christian thinking that saw itself and Jewish practice as mutually exclusive religious systems. On Libanius and Gamaliel, see STERN 1980, vol. 2, p. 580-600. 
tial threat by Christians. ${ }^{101}$ Perhaps nothing agitated Jewish-Christian tensions more than the provocative stated intent of the Emperor Julian to rebuild the Jewish Temple in Jerusalem, ${ }^{102}$ a move with major implications for both Jews and Christians which were immediately obvious to everyone. In fact, in his dissertation Bell makes the suggestion that De Excidio was written in partial response to this attempt, ${ }^{103}$ and there are good reasons for taking such a suggestion very seriously. ${ }^{104}$ Julian had a special relationship with Antioch: it was a base for his dealings with Persia, and it became a hub for his political/religious-philosophical agenda of reinventing the "old religion" and combatting the upstart idiot's guild that was, for him, Christianity. Julian was heralded as divine upon his entering the city on July $18,362 .{ }^{105}$ During his entire reign, Julian held what seems a particularly close, if unstable and explosive, ${ }^{106}$ relationship with Antioch and its people.

If, therefore, Antioch was a hub of Jewish-Christian tension in the late-fourth century; and if it was a city with a distinct connection to the Emperor Julian, an emperor who more than any other exacerbated tensions between Jewish and Christian identity and power; and if, even further, Julian's meddling with Jewish and Christian religion centered on Jerusalem and the Temple, which is the case, the very objects which De Excidio makes its primary narrative

${ }^{101}$ Such a statement could be variously cited, but the essence of the idea is broadly applicable to ancient Christianity and well-articulated by Gavin Langmuir: "Like many non-Christians before them, Christians were anti-Judaic, that is, they were reacting to real characteristics of Jews and Judaism. But Christian anti-Judaism differed markedly from that of non-Christians because the Christians' sense of identity forced them to come to grips with Judaism. Since their sense of identity had so many Jewish components Christians could not simply dismiss Judaism as wrong and irrelevant. To assert the distinctiveness and superiority of their own identity, Christians had to think about Judaism and argue amongst themselves and with Jews that Christians were right and Jews wrong. Thus, for Christians, the ability of Jews to maintain their own identity was not only annoying or hateful in the way ethnic differences so often are; it was an intimate and enduring threat to their sense of identity, a challenge built into their own religion." LANGMUIR 1990, p. 7. Thus Simon states that "The most compelling reason for anti-Semitism was the religious vitality of Judaism." SIMON 1986, p. 232. And Antioch was built for the eruption of such tensions, so to speak: certain sites, such as Daphne, not only held strong claims from both Christians and 'pagans,' but also had strong Jewish ties. DEGIORGI 2016, p. 153, explains how "Talmudic tradition names the cities of Hamath and Ribla as predecessors of Antioch and Daphne," making them "stations of the Babylonian exile" and thus long-established areas of Jewish residence.

${ }^{102}$ For an exhaustive list on the sources of which, see LEVENSON 2004.

${ }^{103}$ BELL 1977, p. 3.

${ }^{104}$ An example might be Titus' implicit criticisms of Jewish belief and practice in De Excidio 41, which sound somewhat like Julian's critique of the Jewish prophets and Christians; I have yet to explore this connection, but owe the idea in large part to David B. Levenson, who mentioned this connection in conversation in the Fall of 2017. Also, one might note that in De Excidio 3.2 the heretic Simon Magus at one points claim that he is about to leave the city (of Rome) because he is "offended by the Galileans" (offensum se dicit a Galilaeis), language descriptive of Christians for which Julian is famous: "Julian, like Epictetus, always calls the Christians Galilaeans because he wishes to emphasise that this was a local creed, 'the creed of fishermen,' and perhaps to remind his reader that 'out of Galilee ariseth no prophet'; with the same intention he calls Christ 'the Nazarene.'” WRIGHT 1961, vol. 3, p. 313.

${ }^{105}$ See here, and in general for Julian in Antioch, LIEU 1989, p. 41-88.

${ }^{106}$ To sum up the drama of the relationship: Julian's “austere personality and mode of life repelled the Syrian populace and the corrupt officials of Antioch. They satirized him in anapaestic verses, and either stayed away from the temples that he restored or, when they did attend in response to his summons, showed by their untimely applause of the Emperor that they had not come to worship his gods. Julian's answer was this satire on himself which he addresses directly to the people of Antioch. But he could not resist scolding them, and the satire on his own habits is not consistently maintained." This satire, of course, is his Misopogon, or The Beard-Hater; WRIGHT 1961, vol. 2, p. 419. 
concentration and takes as grist for its polemical historiography-if all of this is so, would not, per Bell's suggestion, Antioch be a natural place from which a work like De Excidio to have come? In addition to the other evidence, one must wrestle with the peculiar position that Antioch held in the late antique machinations of the Jewish-Christian interface. Finally, and in finer relief, the triumphalist Christian perspective of De Excidio, presuming to speak authoritatively upon the identity and historical place of the Jewish 'other,' fits well within an Antioch where, by the later fourth century, Christianity "had very much the upper hand."107

Here I have summarized and added to arguments partially proffered in Albert Bell's unpublished 1977 dissertation, to the effect that the De Excidio was a product of Antioch or at least an Antiochene author. Mentioned in passing, Bell's argument was never completed or pursued. It thus behooves scholars to examine the evidence, at least before assuming that $D e$ Excidio is a product of Ambrose, or of Rome, both of which are standard assumptions. I have therefore put forward a kind of 'maximalist' argument for Bell's suggestion, lining up all the salient parallels that might contribute to Bell's idea. ${ }^{108}$ Of themselves, none of these constitutes proof positive for establishing De Excidio's provenance. Even taken together, they set nothing in stone, but rather comprise a sizeable collection of related phenomena that have in common a connection with Antioch in late antiquity, particularly the late fourth century. What this collection should do is give scholars pause before associating De Excidio quickly or uncritically with Rome, or even 'Western' traditions more broadly. Though the text is written in Latin, these connections need not obtain. Rather, I would suggest that it is, at very least, quite possible that De Excidio is a product of Antioch, and this I think I have demonstrated. If so, scholarship that does deal with De Excidio must keep in mind this possibility. This will allow the treatment of this work a potentially helpful framework for situating the text, and tentatively expands the scholarly imagination with which we come to understand works like $D e$ Excidio in their linguistic, cultural, and geographical contexts in late antiquity.

\footnotetext{
${ }^{107}$ LiEBESCHUETZ 2015, p. 343.

${ }^{108}$ I have not taken time, due to considerations of space, to treat here Bell's further (and even more tentative) suggestion that Evagrius might have penned De Excidio. In my experience, scholars react to this suggestion with even greater incredulity than they do to the suggestion of Antioch as the text's provenance. But, like Bell's other suggestion, this idea is not ill-conceived. Bell reasons that since it is "highly probable that the author [of $D e$ Excidio] is a devout Christian from Antioch, who could read both Greek and Latin and had the interest and ability to translate Greek literature into Latin, and who was in the west ca. 370," "the most likely candidate may well be Evagrius, presbyter and later bishop of Antioch" (BELL 1977, p. 30-31). Bell conjectures this based upon Evagrius' history of translation, having adapted Athanasius' Greek Vita Antonii into Latin ca. 365, and Evagrius' incidental travels (e.g. to Italy) and relationships (i.e. with Jerome and Ambrose) in the late fourth century. He mentions Jerome's statement that Evagrius had written a number of works never published (De viris illustribus 125), and that, just as Ussani had suggested that De Excidio was published as a posthumous work of Ambrose, so might Evagrius' friends have published his history after his death in 395, and that they might well have left his name off of the work: "Evagrius' controversial role in the ecclesiastical uproar in Antioch would have made his name a detriment to the work and might account for its anonymity" (p. 32). The suggestion of Evagrius as author of De Excidio, like the suggestion of Antioch as place, bears investigation, but deserves its own treatment. The idea that Evagrius was involved in such an enterprise in late ancient Antioch would certainly be interesting given his connections with the Latin language, Libanius and Antiochene literary culture, and other aspects of fourth-century Antiochene culture; see on this URBANO 2013, p. 51-52.
} 


\begin{abstract}
A significant proportion of the meager scholarship that treats Pseudo-Hegesippus, or De Excidio Hierosolymitano, has been spent arguing about whether or not Ambrose was the author of the work. Part and parcel of this argument has been the implicit or explicit location of the text's provenance in Rome. However, there are very good reasons for believing that the text, or the text's author, hailed from Antioch in Syria instead; at the very least he held some significant attachment to that city. Here I argue that the text of De Excidio suggests for itself an Antiochene author. By presenting together a series of evidence that suggests an Antiochene provenance for De Excidio, I submit that scholarship should at least retain the possibility that De Excidio is a product of Antioch (or an Antiochene), as this is a more likely provenance than Rome.
\end{abstract}




\section{BIBLIOGRAPHY}

AdAms 2003 : James Noel AdAMS, Bilingualism and the Latin Language, Cambridge, Cambridge University Press.

Albu 2014 : Emily Albu, The Medieval Peutinger Map: Imperial Roman Revival in a German Empire, Cambridge, Cambridge University Press.

Alciati 2011 : Roberto Alciati, « Review of Chiara Somenzi, Egesippo - Ambrogio: Formazione scolastica e Cristiana a Roma alla metà del IV secolo », JEH, 62, p. 359-361.

ANDERSON 2012 : Mark ANDERSON, Hospitals, Hospices and Shelters for the Poor in Late Antiquity, PhD Dissertation, Yale University, New Haven, CT.

ANDERSON 2017 : Mark ANDERSON, « Mistranslations of Josephus and the expansion of public charity in late antiquity », Early Medieval Europe, 25.2, p. 139-161.

BARDENHEWER 1923 : Otto BARDENHEWER, Geschichte der Altkirchlichen Literatur, Dritter Band: Das Vierte Jahrhundert mit Ausschluss der Schriftsteller Syrischer Zunge, Freiburg im Breisgau, Herder.

BAy 2018 : Carson BAy, The Bible, the Classics, and the Jews in Pseudo-Hegesippus: A Literary Analysis of the Fourth-Century De Excidio Hierosolymitano 5.2, PhD Dissertation, Florida State University, Tallahassee, FL.

Becker, Kondoleon, Newman, Wypyski 2005 : Lawrence Becker, Christine Kondoleon, Richard Newman, Mark T. Wypyski, "The Atrium House Triclinium », in Lawrence Becker, Christine Kondoleon (ed.), The Arts of Antioch: Art Historical and Scientific Approaches to Roman Mosaics and a Catalogue of the Worcester Art Museum Antioch Collection, Worcester, Worcester Art Museum, p. 17-80.

Bell 1977 : Albert A. Bell Jr., An Historiographical Analysis of the De Excidio Hierosolymitano of Pseudo-Hegesippus, PhD Dissertation, University of North Carolina at Chapel Hill, Chapel Hill, NC.

Bell 1980 : Albert A. Bell Jr., « Classical and Christian Traditions in the Work of PseudoHegesippus », Indiana Social Studies Quarterly, 33, p. 60-64.

Bockmuehl 2010 : Markus Bockmuehl, The Remembered Peter in Ancient Reception and Modern Debate (WUNT, 262), Tübingen, Mohr Siebeck.

Den Boeft, Drijvers, den Hengst, Teitler 2013 : J. Den Boeft, J.W. DriJvers, D. Den Hengst, H.C. Teitler, Philological and Historical Commentary on Ammianus Marcellinus XXIX, Leiden, Brill.

Bowersock 1994 : Glen Warren Bowersock, Fiction as History: Nero to Julian (Sather Classical Lectures, 58), Berkeley, University of California Press.

Bowersock, Brown, Grabar 1999 : Glen Warren Bowersock, Peter Brown, Oleg GraBAR (ed.), Late Antiquity: A Guide to the Postclassical World, Cambridge, MA, Harvard University Press.

Bradley 1996 : Nassif Bradley, « Spiritual Exegesis in the School of Antioch », in Nassif Bradley (ed.), New Perspectives in Historical Theology: Essays in Memory of John Meyendorff, Grand Rapids, Eerdmans, p. 343-377. 
Brown, MeIer 1983 : Raymond E. Brown, P. MeIER, Antioch and Rome: New Testament Cradles of Catholic Christianity, New York, Paulist.

BURY 1897 : J. BURY, «Johannes Malalas: The Text of the Codex Baroccianus », Byzantinische Zeitschrift, 6, p. 219-230.

BUSINE 2015 : Aude BUSINE, «Introduction: Religious Practices and Christianization of the Late Antique City », in Aude BUSINE (ed.), Religious Practices and Christianization of the Late Antique City (4 $4^{\text {th }}-7^{\text {th }}$ cent.), Leiden, Brill, p. 1-18.

CAmeron 2009 : Averil CAMERon, « Old and New Rome: Roman Studies in Sixth-Century Constantinople », in Philip Rousseau, Manolis PAPOUTSAKIS (ed.), Transformations of Late Antiquity: Essays for Peter Brown, Burlington, VT, Ashgate, p. 15-36.

CARne 1842 : John Carne, Syria: The Holy Land \& Asia Minor, London, Fisher, Son \& Co.

CARroll 2006 : Maureen CARroll, Spirits of the Dead: Roman Funerary Commemoration in Western Europe (Oxford Studies in Ancient Documents), Oxford, Oxford University Press.

Christensen-Ernst 2012 : Jørgen Christensen-Ernst, Antioch on the Orontes: A History and $a$ Guide, Lanham, MD, Hamilton.

DeGiorgi 2016 : Andrea DeGiorgi, Ancient Antioch: From the Seleucid Era to the Islamic Conquest, Cambridge, Cambridge University Press.

DilKe 1987 : O.A.W. DilKE, «Itineraries and Geographical Maps in the Early and Late Roman Empires », in J.B. Harley, D. WoOdward (ed.), The History of Cartography, Volume 1: Cartography in Prehistoric, Ancient, and Medieval Europe and the Mediterranean, edited by, Chicago, The University of Chicago Press, p. 234-257.

Dilke 1998 [1985] : O.A.W. DiLKe, Greek and Roman Maps, Baltimore, The Johns Hopkins University Press.

DöNITZ 2011 : Saskia DöNITZ, «Historiography among Byzantine Jews: The Case of Sefer Yosippon », in Robert Bonfil, Oded Irshai, Guy G. Stroumsa, Rina Talgam (ed.), Jews in Byzantium: Dialectics of Minority and Majority Cultures (Jerusalem Studies in Religion and Culture, 14), Leiden, Brill, p. 951-968.

Downey 1939 : Glanville DowneY, «The Olympic Games of Antioch in the fourth century A.D. », TAPA, 70, p. 428-438.

Downey 1959 : Glanville DownEY, "Libanius' Oration in Praise of Antioch (Oration XI) », Proceedings of the American Philosophical Society, 103, p. 652-686.

Downey 1963 : Glanville Downey, Ancient Antioch, Princeton, Princeton University Press.

Dunbabin 1999 : Katherine DunBabin, Mosaics of the Greek and Roman World, Cambridge, Cambridge University Press.

DWyer 1931: William Francis Dwyer, The Vocabulary of Hegesippus: A Study in Latin Lexicography (Patristic Studies, 27), Washington, DC, Catholic University of America Press.

ECK 2009 : Werner ECK, « The presence, role and significance of Latin in the epigraphy and culture of the Roman Near East », in H.M. Cotton, R.G. Hoyland, J.J. Price, D.J. Wasserstein (ed.), From Hellenism to Islam: Cultural and Linguistic Change in the Roman Near East, Cambridge, Cambridge University Press, p. 15-42. 
Estève 1987: Dominique EstÈve, L'cuvre historique du pseudo-Hégésippe De bello iudaico : Livre I à IV, PhD Dissertation, Paris, Université Paris Nanterre.

Fant, Reddish 2003 : Clyde E. Fant, Mitchell G. Reddish, A Guide to Biblical Sites in Greece and Turkey, Oxford, Oxford University Press.

Fraser 1996 : Peter M. Fraser, Cities of Alexander the Great, Oxford, Clarendon.

GeIGER 1999 : Joseph GeIGER, « Some Latin Authors from the Greek East », CQ, 49, p. 606617.

GILES 1847 : John A. GILES, William of Malmesbury's Chronicle of the Kings of England, London, Bohn.

GWYNN 2010 : David M. GWYNN, "Archaeology and the 'Arian Controversy' in the Fourth Century ", in David M. GWYnn, Susanne BAngert (ed.), Religious Diversity in Late Antiquity, Leiden, Brill, p. 229-263.

HAHN 1996 : J. HAHN, « Die jüdische Gemeinde im spätantiken Antiochia », in R. JÜTTE, A.P. Kustermann (ed.), Jüdische Gemeinden und Organisationsformen von der Antike bis zur Gegenwart, Vienna, Böohlau, p. 57-89.

HAHN 2004 : J. HAHN, Gewalt und religiöser Konflikt: Studien zu den Auseinandersetzungen zwischen Christen, Heiden und Juden im Osten des Römischen Reiches (von Konstantin bis Theodosius II.), Berlin, Akademie Verlag.

Hahn 2006 : J. Hahn, « Xenodocheion », in Hubert CANCIK, Helmuth SchneIder, Christine F. SalazAR (ed.), Brill's New Pauly. Consulted online on 22 March 2019.

Hall 1999 : Linda Jones HALl, « Latinitas in the Late Antique Greek East: Cultural Assimilation and Ethnic Distinctions », in Shannon N. BYRne, Edmund P. Cueva (ed.), Veritatis Amicitiaeque Causa: Essays in Honor of Anna Lydia Motto and John R. Clark, Wauconda, IL, Bolchazy-Carducci, p. 85-112.

Holwerda 1962 : D. Holwerda, «Le Code de Justinien et sa traduction en grec », Classica et Mediaevalia, 23, p. 274-292.

Horden 2005 : Peregrine Horden, «The Earliest Hospitals in Byzantium, Western Europe, and Islam », Journal of Interdisciplinary History, 35, p. 361-389.

VAN DER HORST 2000 : Pieter VAN DER HORST, « Jews and Christians in Antioch at the End of the Fourth Century ", in Stanley R. PORTER, Brook. W.R. PEARSON (ed.), Christian-Jewish Relations Through the Centuries, New York, T\&T Clark, p. 228-238.

Ihм 1889 : Max Ihm, Studia Ambrosiana: commentatio ex supplementis annalium philologicorum seorsum expressa, Lipsiae, Teubner.

InOWLOCKI 2016: Sabrina INOWLOCKI, "Josephus and Patristic Literature », in Honora Howell Chapman, Zuleika Rodgers (ed.), A Companion to Josephus, Malden, MA, Wiley-Blackwell, p. 356-67.

ISAAC 2009 : Benjamin ISAAC, «Latin in cities of the Roman Near East », in H.M. COTTON, R.G. Hoyland, J.J. Price, D.J. Wasserstein (ed.), From Hellenism to Islam: Cultural and Linguistic Change in the Roman Near East, Cambridge, Camridge University Press, p. 43-72.

JefFreys, JefFreys, Scott 1986: Elizabeth JefFreys, Michael JefFreys, Roger Scott (trans. et ed.), The Chronicle of John Malalas: A Translation (Byzantina Australiensia, 4), Melbourne, Australian National University Press. 
JeREMIAS 1941 : Joachim JEREMIAS, « Die Makkabäer-Kirche in Antiochia », ZNTW, 40, p. 254-255.

Jones 2005 : Christopher P. Jones (trans.), Philostratus, Apollonius of Tyana, Books I-IV (LCL, 16), Cambridge, MA, Harvard University Press.

Joslyn-Siemiatkoski 2009 : Daniel Joslyn-SiemiatKoski, Christian Memories of the Maccabean Martyrs, New York, Palgrave MacMillan.

Kalleres 2015 : Dayna Kalleres, City of Demons: Violence, Ritual, and Christian Power in Late Antiquity, Berkeley, University of California Press.

Kelley 2006: Nicole Kelley, Knowledge and Religious Authority in the PseudoClementines (WUNT, II.213), Tübingen, Mohr Siebeck.

KIHN 1889 : H. KIHN, « Über 'Theōria' und 'Allegoria' nach den verlorenen hermeneutischen Schriften der Antiochener », Theologische Quartalschrift, 20, p. 531-582.

Kleinbauer 1973 : W. Eugene Kleinbauer, « The origin and functions of the aisled tetraconch churches in Syria and northern Mesopotamia », DOP, 27, p. 89-114.

Kletter 2016 : Karen M. KLeTter, « The Christian Reception of Josephus in Late Antiquity and the Middle Ages », in Honora Howell Chapman, Zuleika Rodgers (ed.), A Companion to Josephus, Malden, MA, Wiley-Blackwell, p. 368-381.

Kraeling 1932 : C.H. Kraeling, «The Jewish Community at Antioch», JBL, 51, p. 130160.

Krautheim 2018 : F. KrautheIM, Das öffentliche Auftreten des Christentums im spätantiken Antiochia (STAC, 109), Tübingen, Mohr Siebeck.

LANDGRAF 1902 : G. LANDGRAF, «Die Hegesippus-Frage », Archiv für lateinische Lexikographie und Grammatik, 12, p. 465-472.

LANGMUIR 1990 : Gavin Langmuir, Toward a Definition of Antisemitism, Berkeley, University of California Press.

Levenson 2004 : David B. Levenson, « The Ancient and Medieval Sources for the Emperor Julian's Attempt to Rebuild the Jerusalem Temple », JSJ, 35.4, p. 409-460.

Levi, Levi 1967 : A. Levi, M. Levi, Itineraria picta: Contributo allo studio della Tabula Peutingeriana, Rome, L'Erma di Bretschneider.

LeYERLE 2001 : Blake LEYERLE, Theatrical Shows and Ascetic Lives: John Chrysostom's Attack on Spiritual Marriage, Berkeley, University of California Press.

Liebeschuetz 1972 : J.H.W.G. Liebeschuetz, Antioch: City and Imperial Administration in the Later Roman Empire, Oxford, Oxford University Press.

LieBeschuetz 2015 : J.H.W.G. Liebeschuetz, East and West in Late Antiquity: Invasion, Settlement, Ethnogenesis and Conflicts of Religion (Impact of Empire, 20), Leiden, Brill.

LIEU 1989 : Samuel N.C. LIEU (ed.), The Emperor Julian: Panegyric and Polemic (TTH, 2), $2^{\text {nd }}$ ed., Liverpool, Liverpool University Press.

LUMPE 1968: Adolf LUMPE, «Zum Hegesipp-Problem », Byzantinische Forschungen, 3, p. $165-167$.

MAAS 1900: W. MAAS, «Die Maccabäer als christliche Heilige », Monatsschrift für Geschichte und Wissenschaft des Judentums, 44, p. 145-156. 
Matthews 1994 : J.F. Matthews, « The Origin of Ammian », CQ,44, p. 152-169.

Maxwell 2006 : Jaclyn L. MaXwell, Christianization and Communication in Late Antiquity: John Chrysostom and His Congregation in Antioch, Cambridge, Cambridge University Press.

MAYER 2003 : Wendy MAYER, « John Chrysostom », in John LeEMAns, Wendy MAYER, Pauline Allen, Boudewijn Dehandschutter (ed.), 'Let us Die that we May Live: Greek Homilies on Christian Martyrs from Asia Minor, Palestine and Syria c. 350-c. 450 AD, New York, Routledge, p. 111-161.

McCormick 1935 : J.P. MCCormick, A Study of the Nominal Syntax and of Indirect Discourse in Hegesippus (Patristic Studies, 43), Washington, DC, Catholic University of America Press.

Meeks, Wilken 1978 : Wayne A. Meeks, Robert L. Wilken, Jews and Christians in Antioch in the First Four Centuries of the Common Era, Ann Arbor, University of Michigan Press.

Miller 1964 : K. Miller, Itineraria Romana: Römische Reisewege an der Hand der Tabula Peutingeriana, Stuttgart, Strecker \& Schröder.

Miller 2013 : Timothy S. Miller, «Xenodocheion», in Roger S. Bagnall, Kai BroderSen, Craige B. Champion, Andrew Erskine, Sabine R. Huebner (ed.), The Encyclopedia of Ancient History. Consulted online on 22 March 2019.

Molholt 2005 : Rebecca Molholt, « Mosaic of Hermes Carrying the Infant Dionysos », in Lawrence Becker, Christine Kondoleon (ed.), The Arts of Antioch: Art Historical and Scientific Approaches to Roman Mosaics and a Catalogue of the Worcester Art Museum Antioch Collection, Worcester, Worcester Art Museum, p. 190-195.

MORIN 1914-19 : G. MORIN, «L'Opuscule perdu du soi-disant Hégésippe sur les Machabées », Revue Bénédictine, 31, p. 83-91.

Mras 1958 : Karl Mras, « Die Hegesippus-Frage », Anzeiger der Österreichischen Akademie der Wissenschaften in Wien, 95, p. 143-153.

NeUSNer 1986 : Jacob NeUSNer, Judaism, Christianity, and Zoroastrianism in Talmudic Babylonia, Lanham, MD, University Press of America.

Nicolet, Ilbert, DePaule 2000 : C. Nicolet, R. Ilbert, and J.-C. DePaule (eds), Mégapoles méditerranéenes: Géographie urbaine retrospective (Collection de l'École française de Rome, 261), Paris, Maisonneuve et Larose.

Nock 1954 : A.D. Nock, «The Praises of Antioch », Journal of Egyptian Archaeology, 40, p. $76-82$.

Norman 1992 : A.F. Norman (trans. and ed.), Libanius: Autobiography and Selected Letters, Volume I (LCL, 478), Cambridge, MA, Harvard University Press.

Norman 2000 : A.F. NoRman, Antioch as a Centre of Hellenic Culture as Observed by Libanius (TTH, 34), Liverpool, Liverpool University Press.

OBerhlemAn 1991 : S.M. OBerhleman, Rhetoric and Homiletics in Fourth-Century Christian Literature: Prose Rhythm, Oratorical Style, and Preaching in the works of Ambrose, Jerome, and Augustine (ACS, 26), Atlanta, Scholars.

OBERMANn 1931 : J. OBERMAnN, «The Sepulchre of the Maccabean Martyrs », JBL, 50, p. $250-262$. 
O'KeEFE 2000 : John J. O'KeEFE, «'A Letter that Killeth': Toward a Reassessment of Antiochene Exegesis, or Diodore, Theodore, and Theodoret on the Psalms », JECS, 8, p. 83-103.

Pollard 2015 : Richard Matthew Pollard, « The De Excidio of 'Hegesippus' and the Reception of Josephus in the Early Middle Ages », VIATOR, 46, p. 65-100.

RAIMONDI 2011 : Milena RAIMONDI, « Ambrogio ed Egesippo nella Roma del IV secolo: una nuova prospettiva per un vecchio problema », Rivista di storia della Chiesa in Italia, 65.1, p. 135-147.

Robinson 1837 : George RobInson, Travels in Palestine and Syria, London, Colburn.

RoHrbacher 2002 : David RohrBACHer, The Historians of Late Antiquity, New York, Routledge.

Rolfe 1964 : J.C. Rolfe, Ammianus Marcellinus, Volume II (LCL, 315), Cambridge, MA, Harvard University Press.

RÖNSCH 1883: H. RÖNSCH, «Die lexikalischen Eigentümlichkeiten des sogenannten Hegesippus », Romanische Forschungen, 1, p. 256-321.

RouwhORST 2005 : Gerard RouwhORST, «The Emergence of the Cult of the Maccabean Martyrs in Late Antique Christianity », in Johan LeEMANs (ed.), More Than a Memory: The Discourse of Martyrdom and the Construction of Christian Identity in the History of Christianity (Annua nuntia Lovaniensia, 51), Leuven, Peeters, p. 81-96.

SANDWELl 2007 : Isabella SANDWELl, Religious Identity in Late Antiquity: Greeks, Jews and Christians at Antioch, Cambridge, Cambridge University Press.

ScHOlz 1909: Otto SchOlz, "Die Hegesippus-Ambrosius-Frage », Sdraleks Kirchengeschichtliche Abhandlungen, 8, p. 149-195.

Schoolman 2010 : Edward McCormick Schoolman, Civic Transformation of the Mediterranean City: Antioch and Ravenna, 300-800 CE, PhD Dissertation, University of California, Los Angeles, Los Angeles, CA.

SHEPARDSON 2008: Christine SHEPARDSON, Anti-Judaism and Christian Orthodoxy: Ephrem's Hymns in Fourth-Century Syria (Patristic Monograph Series, 20), Washington, DC, The Catholic University of America Press.

SHEPARDSON 2014 : Christine SHePARdson, Controlling Contested Places: Late Antique Antioch and the Spatial Politics of Religious Controversy, Berkeley, University of California Press.

Simon 1986 : Marcel Simon, Verus Israel: A Study of the Relations between Christians and Jews in the Roman Empire (AD 135-425), Oxford, Oxford University Press.

Sizgorich 2009 : Thomas Sizgorich, Violence and Belief in Late Antiquity: Militant Devotion in Christianity and Islam (Divinations: Rereading Late Ancient Religion), Philadelphia, University of Pennsylvania Press.

SomenZI 2005 : Chiara SomeNZI, «Affinità di formazione scolastica tra Ambrogio e lo ps. Egesippo?», Quaderni di Acme, 73, p. 741-780.

SomenZI 2009 : Chiara SomenZI, Egesippo - Ambrogio: Formazione scolastica e Cristiana a Roma alla metà del IV secolo (Studia Patristica Mediolanensia, 27), Milan, Vita e Pensiero. 
SPINKA, Downey 1940 : Matthew SPINKA, Glanville DownEy (trans. and ed.), Chronicle of John Malalas, Books VIII-XVIII: Translated from the Church Slavonic, Chicago, The University of Chicago Press.

Stenger 2009 : J. Stenger, Hellenische Identität in der Spätantike: Pagane Autoren und ihr Unbehagen an der eigenen Zeit (Untersuchungen zur antiken Literatur und Geschichte, 97), Berlin, de Grutyer.

STERn 1980 : M. STERn, Greek and Latin Authors on Jews and Judaism, 3 volumes, Jerusalem, Israel Academy of Arts and Sciences.

TAlbert 2010 : Richard J.A. TAlBert, Rome's World: The Peutinger Map Reconsidered, Cambridge, Cambridge University Press.

TAPPENDEN 2014 : Frederick S. TAPPENDEN, « On the Difficulty of Molding a Rock: The Negotiation of Peter's Reputation in Early Christian Memory », in Tom ThATCHER (ed.), Memory and Identity in Ancient Judaism and Early Christianity: A Conversation with Barry Schwartz, (Semeia, 78), Atlanta, SBL, p. 263-288.

TERnANT 1953 : P. TERnANT, «La $\theta \varepsilon \omega \rho i \alpha$ d'Antioch dans le cadre des sens de l'écriture », Biblica, 34, p. 135-158.

Thackeray 1967 : Henry St. J. Thackeray (trans.), Josephus, The Jewish War, Books I-III (LCL), Cambridge, MA, Harvard University Press.

ThaCKeray 1957 : Henry St. J. Thackeray (trans.), Josephus, The Jewish War, Books IVVII (LCL), Cambridge, MA: Harvard University Press.

Thrower 2008 : Norman J.W. Thrower, Maps and Civilization: Cartography in Culture and Society, $3^{\text {rd }}$ ed., Chicago, The University of Chicago Press.

Traube 1884 : Ludwig Traube, «Zum lateinischen Josephus », Rheinisches Museum für Philologie, 39, p. 477-478.

Urbano 2013 : Arthur P. Urbano, The Philosophical Life: Biography and the Crafting of Intellectual Identity in Late Antiquity (Patristic Monograph Series, 21), Washington, DC, The Catholic University of America Press.

USSANI 1906 : Vincenzo USSANI, « La questione e la critica del così detto Egesippo », Studi italiani di filologia classica, 14, p. 245-361.

UsSANI 1933 : Vincenzo UsSANI, « Su le fortune medievali dell'Egesippo », Rendiconti della Pontificia Accademia di Archeologia, 9, p. 107-118.

Ussani, Mras 1960 [1932]: Vincenzo UsSani, Karl Mras (eds), Hegesippi qui dicitur historiae libri V (CSEL, 66), 2 volumes, Vienna, Hölder-Pichler-Tempsky.

VACCARI 1920 : A. VACCARI, « La $\theta \varepsilon \omega \rho i ́ \alpha$ nella scuola esegetica di Antiochia », Biblica, 1, p. 3-36.

VANDERSPOel 1995 : John VANDERsPoel, Themistius and the Imperial Court: Oratory, Civic Duty, and Paideia from Constantius to Theodosius, Ann Arbor, University of Michigan Press.

VINSON 1994 : Martha VINSON, «Gregory Nazianzen's Homily 15 and the Genesis of the Christian Cult of the Maccabean Martyrs », Byzantion, 64, p. 166-192.

Vogel 1880 : Friedrich Vogel, De Hegesippo, qui dicitur, Iosephi interprete, Munich. 
Wallace-Hadrill 1982 : D.S. Wallace-Hadrill, Christian Antioch: A Study of early Christian Thought in the East, Cambridge, Cambridge University Press.

WeBer, CAesar 1864 : C.F. Weber, J. CAesar (eds), Hegesippus qui dicitur sive Egesippus De Bello Judaico Ope Codicis Cassellani recognitus, Marburg, Elwert.

Weber 1976 : E. Weber, Tabula Peutingeriana: Codex Vindobonensis 324, 2 volumes, Graz, Akademische Druck- und Verlagsanstalt.

WeNZEL 2010 : Aaron WenZEL, « Libanius, Gregory of Nazianzus, and the Ideal of Athens in Late Antiquity », Journal of Late Antiquity, 3, p. 264-285.

WEYMAN 1905-06 : C. WEYMAN, « Sprachliches und Stilistisches zu Florus und Ambrosius », Archiv für lateinische Lexikographie und Grammatik, 14, p. 41-61.

WIERSCHOWSKI 1995 : Lothar WIERSCHOWSKI, Die regionale Mobilität in Gallien nach den Inschriften des 1. bis 3. Jahrhunderts $n$. Chr.: Quantitative Studien zur Sozial- und Wirtschaftsgeschichte der westlichen Provinzen des römischen Reiches (Historia, 91), Stuttgart, Franz Steiner.

WILKEN 1983 : Robert Louis WiLKEN, John Chrysostom and the Jews: Rhetoric and Reality in the Late $4^{\text {th }}$ Century, Berkeley, University of California Press.

WindHAM 2005 : Anne Leinster WindHAM, « Small Finds », in Lawrence BECKER, Christine Kondoleon (ed.), The Arts of Antioch: Art Historical and Scientific Approaches to Roman Mosaics and a Catalogue of the Worcester Art Museum Antioch Collection, Worcester, Worcester Art Museum, p. 266-273.

WRIGHT 1961 : Wilmer Cave WRIGHT, The Works of the Emperor Julian (LCL), 3 volumes. Cambridge, MA, Harvard University Press.

Young 1997 : Frances M. Young, Biblical Exegesis and the Formation of Christian Culture, Cambridge, Cambridge University Press. 